\title{
Şehir İçi Otel Odalarının Banyolarında Kullanılabilirlik Kavramının Tekerlekli Sandalye Kullanıcıları Açısından Analizi: Pendik'te Üç Otel
}

\author{
Neslihan YILDIZ ${ }^{1}$, M. Atilla SÖĞÜT ${ }^{2}$
}

Öz

Engelli bireyler konutları başta olmak üzere bulundukları tüm yapılarda intiyaçları doğrultusunda birtakım sorunlarla karşılaşmakta ve bu sorunlar onların yaşamını çok daha zor kılmaktadır. Bu yapılardan biri olan şehir içi otelleri, kişilerin geçici bir süre için dinlenme, çalışma ve eğlenmesi amacıyla tasarlanmış konutlar olarak düşünülebilir. Buna bağlı olarak herhangi bir engele sahip olmayan bireyler kadar toplumun önemli bir bölümünü oluşturan engelli bireyler de tatil ve iş için bu alanları kullanacaklardır. Toplumsal mekânın her alanında yer almak; aynı zamanda tüm engelli bireylerin temel intiyaç, talep ve istekleri arasında yer almak demektir. $\mathrm{Bu}$ bağlamda engelli bireylerin, konakladıkları otellerde kullanılabilirliklerinin sağlanması açısından otel işletmelerinin tasarımları büyük önem taşımaktadır. Tüm bunlardan yola çıkılarak, çalışmada engelli sınıflarından biri olan bedensel engelliler ele alınmıştır. Bedensel engelli bireyler, kullanım kısıtılığı yaşamaları sebebiyle tasarımdan kaynaklanan birçok engellerle karşılaşmaktadırlar. Bu engellerin giderilebilmesi için, mekânların tüm detaylarıyla düşünülüp ele alınmaları ve ergonomik bir şekilde tasarlanmaları gerekmektedir.

Çalışma, şehir içi otellerinin iç mekân kullanılabilirliklerinin bedensel engelliler açısından uygunluğunu araştırmak amacıyla yapılmıştır. Çalışmada şehir içi otel yapılarının bedensel engellilere yönelik düzenlemeleri hakkında mevcut durum tespitleri yapılarak, üç farklı şehir içi otel (5 yıldızı) yapısı incelenmiştir. Bu doğrultuda çalışmaya örnek olan üç adet şehir içi otelinin kullanılabilirlik bağlamında analizi, ulusal standartlar ve mevzuatlar gereği tüm ölçüler ve tasarımlar doğrultusunda fotoğraflanarak incelenmiş ve tablolaştırılmıştır. Tüm bulgular değerlendirilip, bu otellerin kullanılabilirliklerini artırmak adına neler yapılabileceği konusunda öneriler sunulmuştur.

Anahtar Kelimeler: Şehir içi Otelleri, Bedensel Engelli, Tekerlekli Sandalye Kullanıcıları, Kullanılabilirlik.

\footnotetext{
${ }^{1}$ Maltepe Üniversitesi, Mimarlık ve Tasarım Fakültesi, İç Mimarlık Bölümü

${ }^{2}$ Mimar Sinan Güzel Sanatlar Üniversitesi, Mimarlık Fakültesi, l̇ç Mimarlık Bölümü

* Bu çalışma Dr. Öğr. Üyesi M. Atilla SÖĞÜT danışmanlığında, birinci yazarın "istanbul Şehir İçi Otellerin Bedensel Engelliler Açısından Ulaşılabilirlik, Erişilebilirlik ve Kullanılabilirlik Kapsamında Değerlendirilmesi”, (Yıldız., N) Yayımlanmamış Doktora Tezi, İstanbul, Mimar Sinan Güzel Sanatlar Üniversitesi, Fen Bilimleri Enstitüsü, 2017 künyeli tezinden üretilmiştir.

* ilgili yazar/Corresponding author: neslihanyildiz@maltepe.edu.tr Gönderim Tarihi / Received Date: 30.05.2020 Kabul Tarihi / Accepted Date: 30.10.2020
} 


\title{
Analysis of the Concept of Usability in Urban Hotels in Terms of Physically Disabled: Three Hotels in Pendik
}

\begin{abstract}
Individuals with disabilities face some problems in their buildings, especially in their homes, in line with their needs, and these problems make their lives a lot more difficult. One of these systems, City hotels can be considered as residences designed for temporary rest, work and entertainment. Accordingly, individuals with disabilities, which constitute a significant part of the society as well as individuals without any disabilities, will use these areas for vacation and work. To take part in all areas of social space; it also means being among the basic needs, demands and wishes of all people with disabilities. In this context, the designs of hotel businesses are of great importance in terms of ensuring the availability of disabled individuals in the hotels where they stay. Based on all of this, in this study, physically disabled people, one of the disabled classes, are discussed. Individuals with physical disabilities face many obstacles stemming from the design due to their limited use. In order to overcome these obstacles, the spaces need to be considered and handled in all details and designed ergonomically.
\end{abstract}

The study was carried out to investigate the suitability of indoor hotels of city hotels for the physically disabled. In the study, three different city hotels (5-stars) buildings were examined by determining the current situation about the regulations of the city hotel buildings for the physically disabled. In this context, the analysis of three city hotels, which are examples of the study, in the context of usability, has been photographed, examined and tabulated in accordance with all dimensions and designs in accordance with national standards and regulations. All findings are evaluated and suggestions are made on what can be done to increase the availability of these hotels.

Key Words: City Hotels, Physically Handicapped, Wheelchair Users, Usability.

\section{GíRiş}

Dünya Sağlık Örgütü (WHO) küresel ölçek düzeyinde bakıldığında dünya nüfusunun takribi olarak \%10 kesimini bedensel engellilerin oluşturduğunu belirtmektedir. Bu oran temel alınarak Dünyada yaklaşık 500 milyon bedensel engelli birey bulunduğunu ve bu çember genişletilerek aileler ile birlikte ele alındığında ise yaklaşık 1,5 milyar insanı doğrudan ilgilendiren toplumsal bir sorun olarak karşımıza çıkmaktadır. Dolayısıyla bedensel engelliler bütününde düşünüldüğünde, toplumsal mekâna katılım, temel intiyaçları karşılayabilme ve sosyalleşme açısından tasarımın bir parçası olan mekânsal düzenlemelerin önemine dikkat çekilmelidir. Bu noktada bedensel engellilerin kamusal alanlara (kentsel mekân, yapısal tesis vb.) güvenli, konforlu bir şekilde erişebilmeleri ve bu mekânlar içerisinde bulunan mevcut donatıları rahat kullanılabilmeleri adına bir takım mekânsal düzenlemelerin getirildiği görülmektedir. Sonuç olarak TS 9111 sayılı "Özürlüler ve Hareket Kısıtııı̆ı Bulunan Kişiler İçin Binalarda Ulaşılabilirlik Gerekleri” standardının getirilmesiyle, engellilere yönelik dış ve iç mekân düzenleme ölçütleri belirlenerek yasal hale getirilmiştir.

Bu araştırmada, İstanbul İli, Pendik İlçesi'nde hizmet performansı açısından beş yıldızı otel konumunda olup, ayrıca konaklama tesisi olmasının yanında gere konferans-sergi ve spor-eğlence gerekse toplantı-etkinlik bağlamında çeşitli mekânsal talepler 
doğrultusunda hizmet veren şehir içi otelleri ele alınmıştır. Şehir içi otellerin seçilmesindeki temel ölçütler, konumsal özellikleri sayesinde kolay erişilebilir olması, çeşitli sosyal-kültürel etkinliklere ev sahipliği yapması ile imkânları açısından sosyal statüyle doğrudan ilişkili geniş bir kullanıcı portföyü sunmasıdır.

Bu çalışmanın amacı; seçilen örnek şehir içi otellerin oda banyolarına ait kapıların özellikleri ve aksamları, lavabo ve çevresi, klozet ve çevresi, yıkanma birimi ve çevresi, zemin döşeme malzemesi olmak üzere kullanım elemanlarının TS 9111 sayılı "Özürlüler ve Hareket Kısıtılığı Bulunan Kişiler İçin Binalarda Ulaşılabilirlik Gerekleri" standardı temelinde detaylı bir şekilde incelenerek, tekerlekli sandalye kullanıcıları yönünden kullanılabilirlik sorunlarının tespit edilmesi ve çözüm önerileri sunulması için görüş geliştirilmesidir.

Çalışmada, kavramsal-kuramsal olarak arka planın kurulması, örneklem alanının belirlenmesi, otellerin iç mekân kullanım donanımlarının gruplandıııması, yerinde tespit çalışmaları ile fotoğraflanması ve ölçülendirme yapılması, elde edilen bulguların Standartlar gereklilikleri ile karşılaştırmalı olarak değerlendirilmesine dayalı bir yöntem izlenmiştir.

Araştırma kapsamında tekerlekli sandalye kullanıcılarının yasal mevzuat temelinde kurulan engelli tasarım ölçütleri bağlamında iç mekândaki kullanılabilirliklerinin sorgulanması ve fiziksel kısıta dayalı problemlerinin tespiti, gerek mevcut yasal mevzuatın ileride yapılacak olan şehir içi otel yapılarının mimari/iç mimari tasarımlarına yansıması gerekse engelli bireylerin toplumsal yaşama katılımları ve sosyal hayatta aktif rol almaları amacıyla büyük önem arz etmekte ve gereklilik taşımaktadır. Ayrıca bu alanda gerçekleştirilecek daha kapsamlı bir bilimsel araştırmayı öncelemesi bakımından önemli görülmektedir.

\subsection{Engelli Kavramı}

Engellilik kavramı ele alındığında engelli tanımıyla ilgili pek çok tanımla karşılaşılmaktadır. Çalışmanın standartları bağlamında temeline dayanan Türk Standartları Enstitüsü tarafından engelli;

"Özür, vücut fonksiyonlarının kullanımında fiziki kısıtlılık veya kayıptır. Bedensel özürlü, normal insan hareketliliğine sahip olmayan ve hareket organlarında eksiklik ve özür bulunduğundan yardımcı cihaz ve araçlarla hareket edebilen fiziki özürlü kişidir. Tekerlekli sandalye kullanan özürlü, yürümesi sakıncalı görülen veya yürüme engelli olan, yardımsız veya yardımlı olarak tekerlekli sandalye kullanarak hareket edebilen kişidir" şeklinde tanımlanmaktadır (TS, 9111, 1991). Bedensel engelli ise; "doğum öncesi, doğum sırası ve doğum sonrası dönemde herhangi bir nedene bağlı olarak iskelet (kemik), kas ve sinir sistemindeki bozukluklar sonucu, bedensel yeteneklerini çeşitli derecelerde kaybeden, toplumsal yaşama uyum sağlama ve günlük yaşamdaki gereksinimlerini karşılamada güçlükleri olan, bu nedenlerle korunma, bakım, rehabilitasyon, danışmanlık ve destek hizmetlerine intiyaç duyan" kişiye denir (MEB, 2008, s.3). Bu bireylerin birçok farklı sebeple kaba ve ince motor becerileri olumsuz olarak etkilenmiş, kendilerinden beklenen işlevsel hareket ve becerileri yerine getirme noktasında kısıtlanmışlardır (MEB, 2008, s.4). Dolayısıyla bireyler hareket edebilmek için yardımcı bazı araç gereçlere gereksinim duymaktadırlar(Yılmaz ve Aydın, . Bu araç gereçler tekerlekli sandalye, yürüteç veya koltuk değneği gibi yardımcı yürüme araçları olarak farklılık göstermektedir. 


\subsection{Kullanılabilirlik Kavramı}

Uluslararası Standartlar Organizasyonu tarafından kullanılabilirlik; "belirlenen bir çevrede, bir ürünün ya da mekân donatısının belirli kullanıcılar tarafından belirli amaçlarla etkili, verimli ve belirli bir kullanım çerçevesinde memnuniyetle kullanabilme derecesi olarak" tanımlanmaktadır (ISO, 9241). Bu tanıma göre kullanılabilirlik; kent ölçeğindeki ulaşılabilirlik kavramından ve mekân ölçeğindeki erişilebilirlik kavramında ayrılmaktadır.

Bir mekânın kullanılabilir kılınması için, o mekânın etkin ve verimli kullanılabilmesi, mekân ile ilgili özelliklerin bir sonraki kullanımda bellekte kalabilmesi ve mekânsal öğelerin özellikleri açısından tutarlılık göstermesi gerekmektedir (Demirkan, 2015, s.2).

Özel gereksinimlere sahip bireyler olarak engelli, yaşlı kişilerin ikinci bir bireye ihtiyaç duymadan, günlük yaşam gereksinimlerini karşılayabilmeleri, farklı çevre ve mekânlara erişebilmeleri adına bir takım düzenlemeler getirilmiştir. Ülkemizin de dahil olduğu pekçok farklı ülkede geliştirilen standartlar (ADA, 2010; ANSI A117.1, 1986; BS 5810, 1979; TS 9111, 1991) ve düzenlemeler, bu özel kullanıcı grupları için belirli özel tasarım çözümlerini de beraberinde getirmiştir (Muğan, 2015, s.44).

\section{3. Şehir İçi Otel Kavramı}

Şehir içi otelleri, diğer otellere göre daha geniş, daha konforlu, lüks ve çeşitli mutfaklara ait restoranlara sahip, moda, sosyal aktiviteler ve ticaretle ilgili farklı aktivitelerin yapılmasına olanak sağlayan otellerdir (Karahasanoğlu, 2004, s.8). Genellikle bu oteller, büyük iş merkezlerinin ve alışveriş merkezlerinin olduğu şehrin prestij alanlarında inşa edilirler. Kolay ulaşılan, yoğunluğu fazla olan yerlerdeki şehir otelleri iş toplantıları, kongre ve sosyal aktiviteler için en ideal yapılardır. Şehir içi otelleri aynı zamanda pek çok olanaklarıyla konfor sunarak, her bir konuğun tüm gereksinimlerini karşılayacak biçimde donanıma sahip yapılardır. Bu statüdeki oteller hizmet ve olanaklarına, engelli engelsiz tüm bireylerin eşit bir şekilde erişimini sağlayacak nitelikte olmalıdır (Burak, 2018, s.132).

Bugün iş toplantıları, çeşitli faaliyetler ve konferanslar olmak üzere karşılıklı iletişim tabanlı etkinlikler için tercih edilen mekânlar dizisinde talepleri karşılayabilecek yetkinlikte oteller de yer seçmişlerdir. Herşeyden önce şehir içi otellerin konum itibariyle merkezde bulunması ve ulaşım rahatığı açısından olanak sunması, oteli iş amaçlı tercih eden otel kullanıcıları tarafından tercih sebebi olmuştur (Akçakaya, 2014, s.xviii).

\subsection{Tekerlekli Sandalye Kullanıcıları İçin Gerekli Alanlar ve Ölçüler}

Bir mekânın engelleyici özellikte olması; aynı zamanda o mekânın günlük yaşamın çevresindeki tüm eylemleri doğrudan etkileyeceğinden yaşanabilirlik bağlamında ayrı bir önem taşıdığı anlamına gelmektedir. Dolayısıyla fiziksel düzenlemeler yapılarak yaşam çevrelerindeki engellerin kaldırımasıyla tüm bireylere sosyal/aktif yaşama katılım ve yaşamı idame ettirme noktasında gerekli koşullar sağlanmış olacaktır (Yılmaz, 2005, s.76).

Engelli sınıfları içerisinde, gerek dış mekân gerekse iç mekân düzenlemesine ilişkin en çok gereksinime sahip olan grup bedensel engellilerdir. Bedensel engelli bireyler yürüme-hareket etme eylemlerini gerçekleştirebilmek için yardımcı araç gereçlere gereksinim duyarlar ve bu araç gereçler mekân tasarımında bir takım düzenlemeler 
gerektirmektedirler (Yılmaz, 2005, s.79). Bu engel gruplarından tekerlekli sandalye kullanıcılarının kullandıkları araç gereçlerle sahip oldukları antropometrik ölçüler aşağıdaki gibidir:

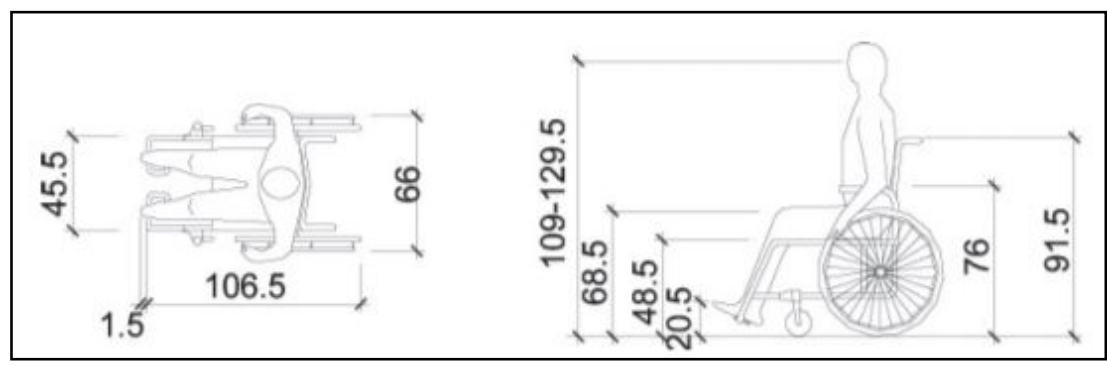

Şekil 1. Tekerlekli sandalye ölçüleri (TS 9111).

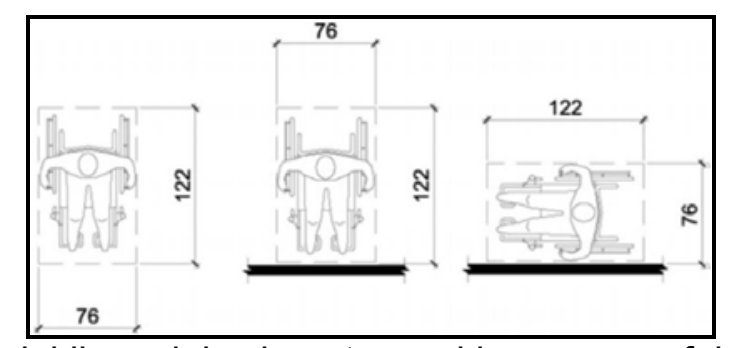

Şekil 2. Tekerlekli sandalye boyut ve yaklaşma mesafeleri (TS 9111).

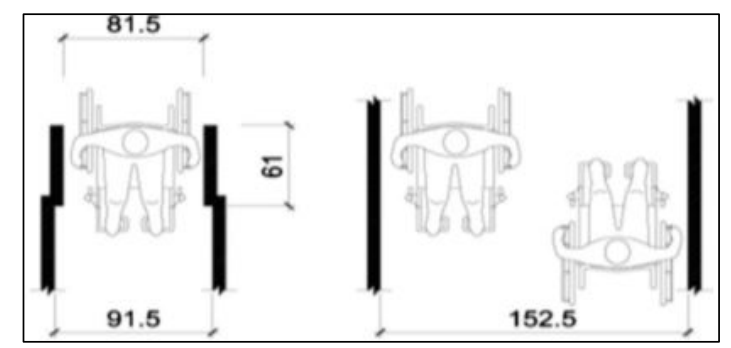

Şekil 3. Tekerlekli sandalye kullanıcılarının geçişi için gerekli genişlikler (TS 9111).
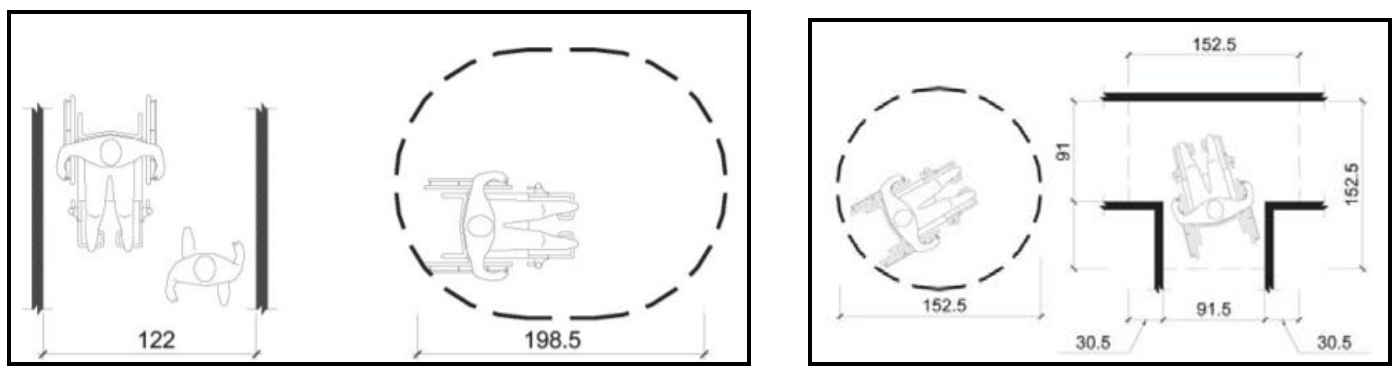

Şekil 4. Tekerlekli sandalye kullanıcıları için geçiş ve dönüş alan ölçüleri (TS 9111).

Kullanılabilirlik bağlamında çalışmada ele alınan parametrelere dair tekerlekli sandalye kullanıcıları için banyo tasarımında gerekli alanlar ve ölçüler ise aşağıdaki gibidir:

\section{BANYO MEKÂNLARINDA TEKERLEKLİ SANDALYE KULLANICILARI IÇiN UYULMASI GEREKEN STANDARTLAR}

Otel odalarında banyolar, şaft ve tesisat birliğinin sağlanması açısından mümkün olabildiğince koridorlara yakın olarak kurgulanmalıdır. Temel intiyaçların rahatlıkla karşılanabileceği alanda konumlandırılan banyoların, ayrıca tekerlekli sandalye kullanıcıları açısından erişilebilirliği ve kullanılabilirliği sağlanmış olacaktır. 
Banyo net döşeme alanı; banyo girişinin konumuna ve tekerlekli sandalye ile yıkanma birimine (küvet, duş teknesi) yaklaşım şekline göre tasarlanır (Şekil 5-6-7-8) (TS 9111).

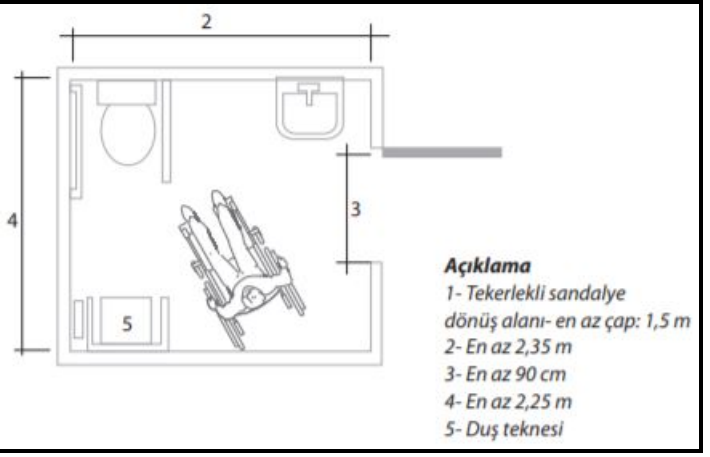

Şekil 5. Banyo örneği ve ölçüleri (TS 9111).

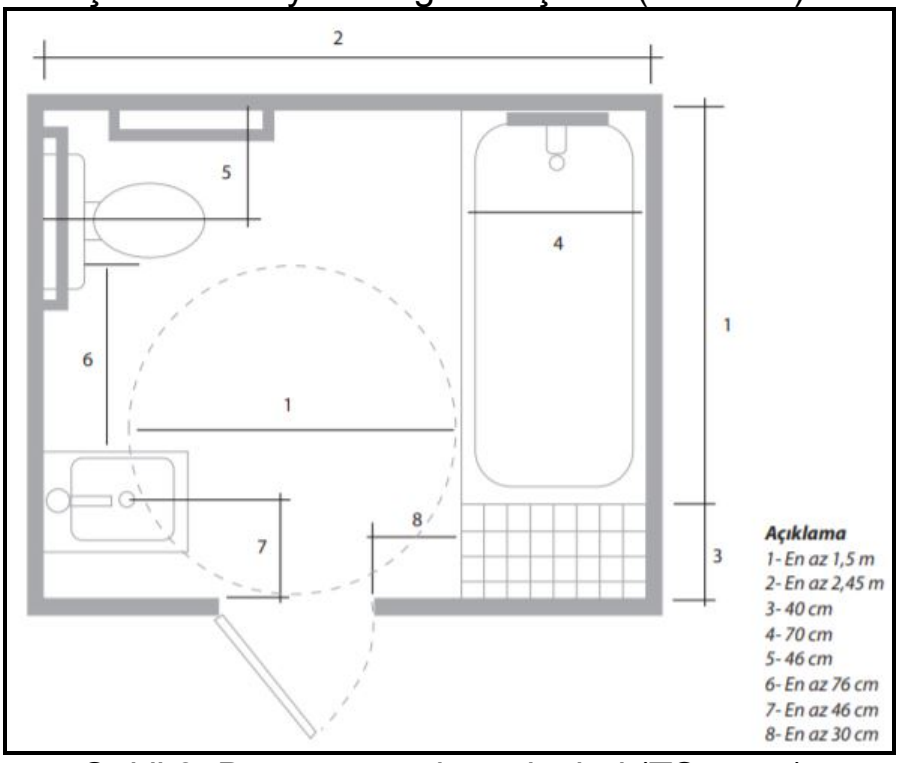

Şekil 6. Banyo örneği ve ölçüleri (TS 9111).

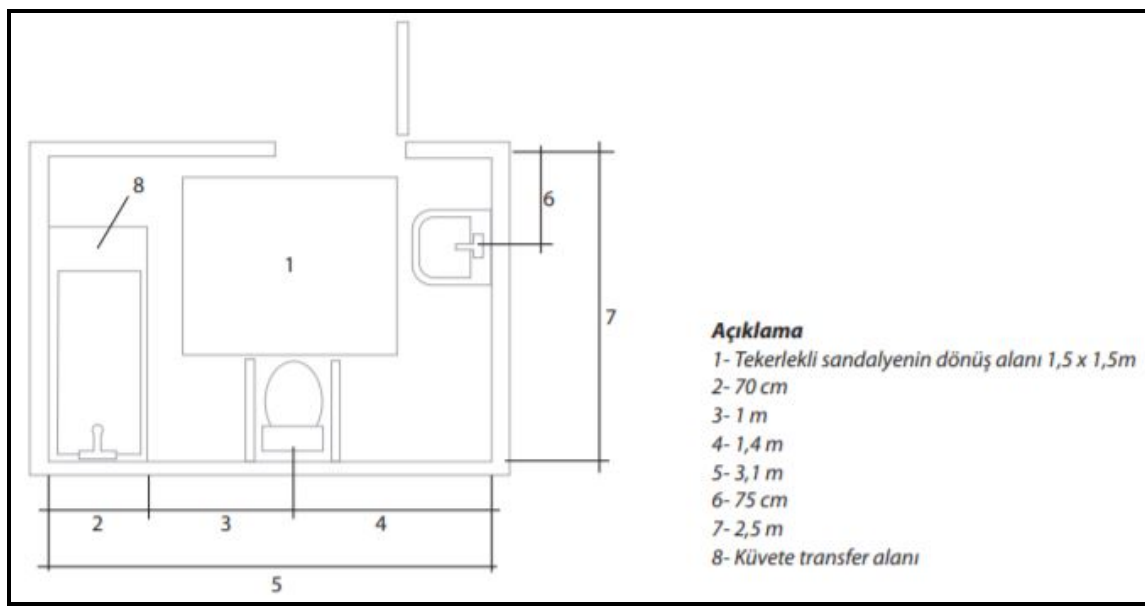

Şekil 7. Banyo örneği ve ölçüleri (TS 9111). 


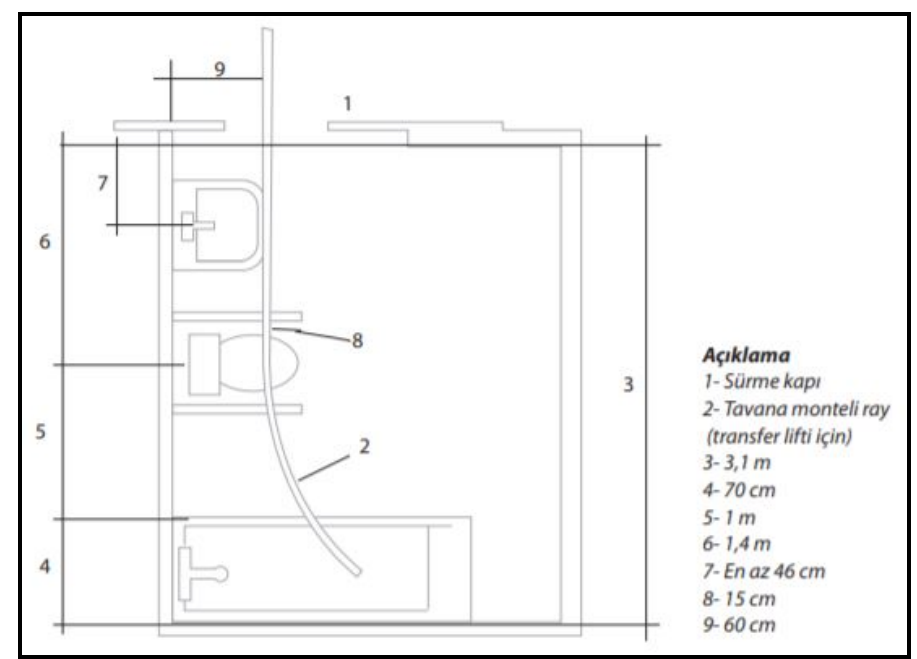

Şekil 8. Transfer lifti özelliğine sahip banyo örneği (Ray monteli) (TS 9111).

\subsection{Kapıların Özellikleri ve Aksamları}

Kapıların açılma yönü kolaylıkla açılabilmesi açısından olabildiğince koridora dik şekilde olmalıdır. Kapının $90^{\circ}$ açılması durumunda net genişlik; iç kapılarda $90 \mathrm{~cm}$.'den az, bağımsız bölüm kapılarında ise $100 \mathrm{~cm}$.'den az olmamalıdır. Ayrıca kapı net yüksekliği en az $210 \mathrm{~cm}$. olmalıdır (Şekil 9-10) (TS 9111).

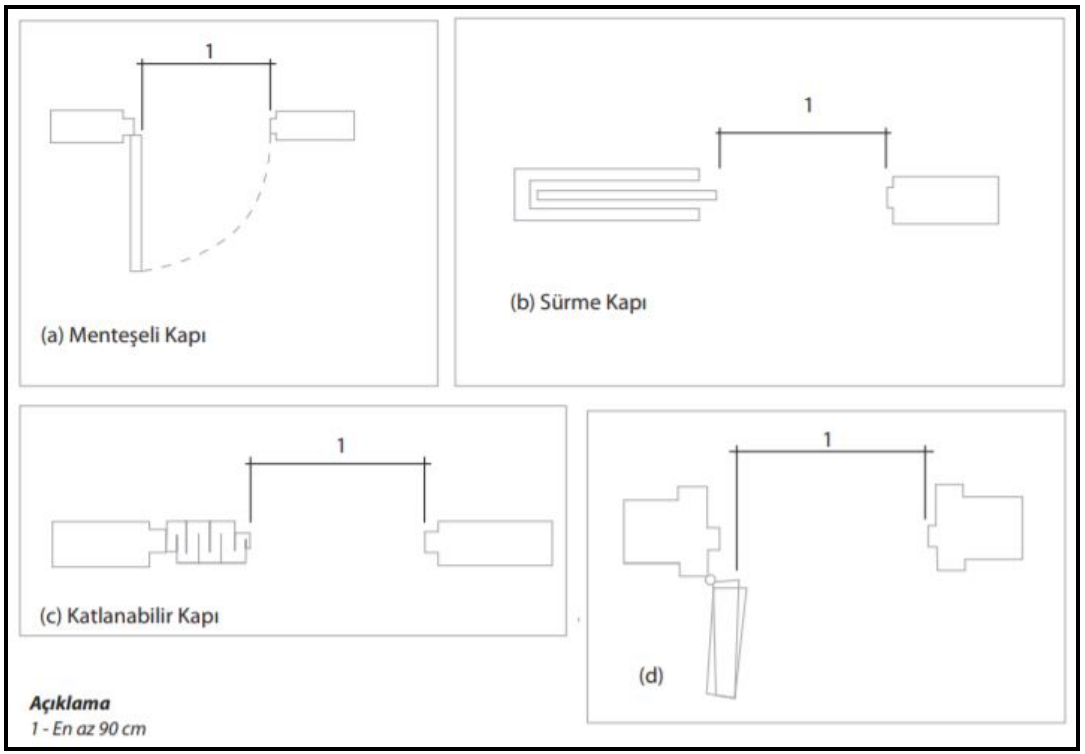

Şekil 9. Kapı net genişliği ölçüleri (TS 9111).

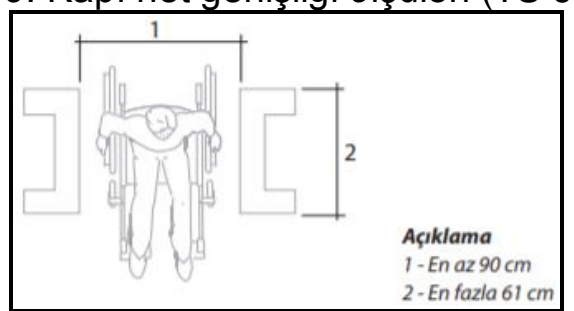

Şekil 10. Kapı geçiş derinliği için ölçüler (TS 9111).

Kapılarda eşik yapılmaması önerilmektedir. Eşik yerine pahlanmış seviye farkı oluşturulması ve yer kaplamasının eğiminin ayarlanması tercih edilmelidir. Eşik 
yapılmasının zorunlu olduğu durumlarda; eşik yüksekliği $1,3 \mathrm{~cm}$.'den yüksek olmamalıdır. Tekerlekli sandalye kullanıcıları için eşikler iyi sabitlenmiş ve pahlı formda olmalı, malzeme olarak ise lastik eşikler tercih edilmesi tavsiye olunur (Şekil 11) (TS 9111).

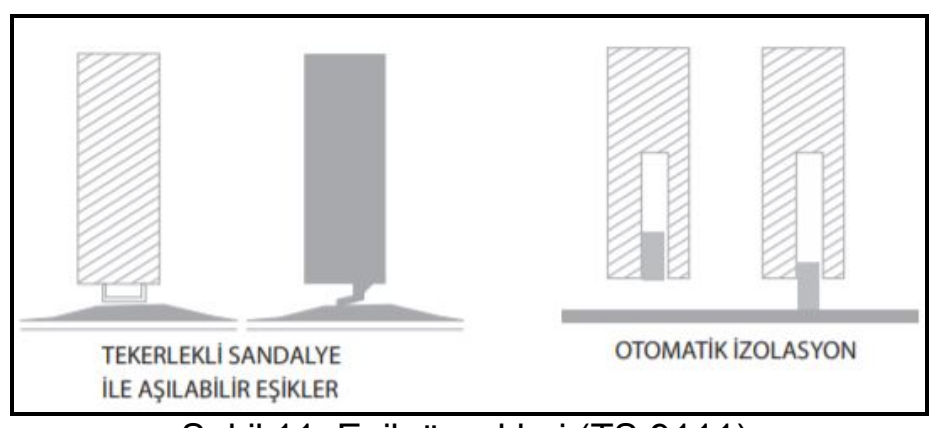

Şekil 11. Eşik örnekleri (TS 9111).

Kapıya ait aksamların (kapı kolu, kilitler vb.) tek elle ve ellerini kullanamayanlar için ise kavrama gerektirmeyecek şekilde kullanıma elverişli olmalıdır (Şekil 12). Biçim olarak "U" biçimli kapı kulpları, işleyiş olarak da itmeli kollu aksamlar tavsiye edilmektedir. Kapı kolunun yerden yüksekliği $90-110 \mathrm{~cm}$. aralığında olmalıdır. Kapı aksamı kolay anlaşılabilir ve her iki taraftan da kullanılabilir nitelikte olmalıdır (Şekil 13-14) (TS 9111).

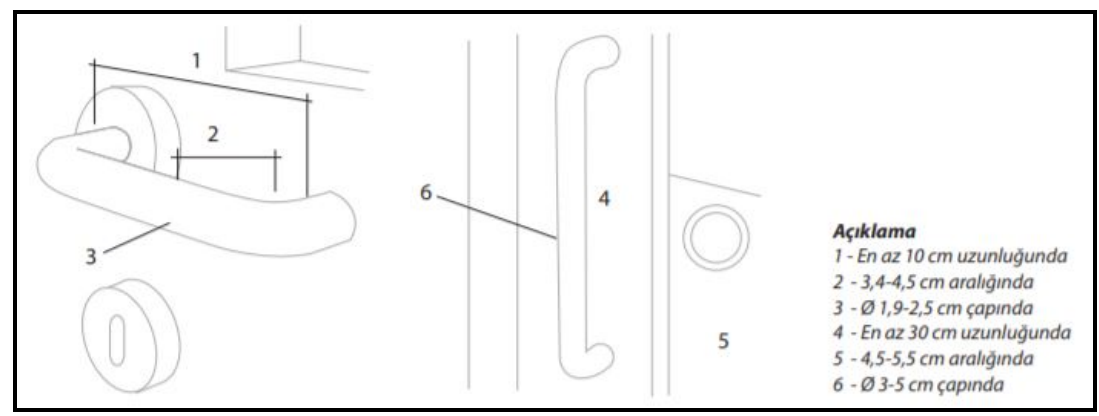

Şekil 12. Tavsiye edilen kapı kolu ve aksamı (TS 9111).

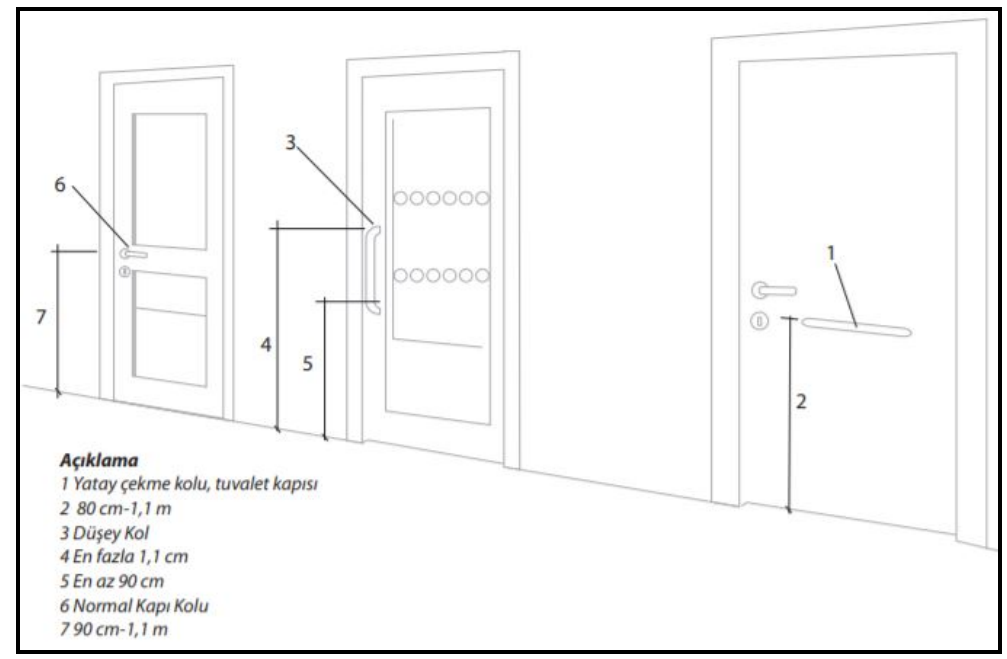

Şekil 13. Kapı kolu ve aksamına ait yükseklik ölçüleri (TS 9111). 

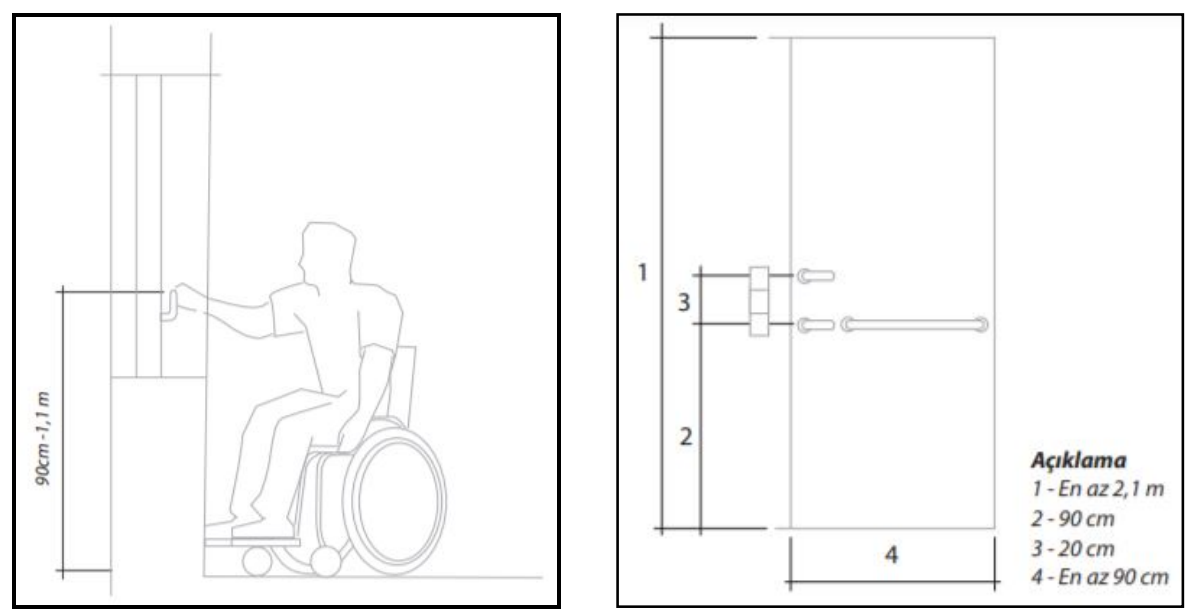

Şekil 14. Kapı kolu ve aksamına ait yükseklik ölçüleri (TS 9111).

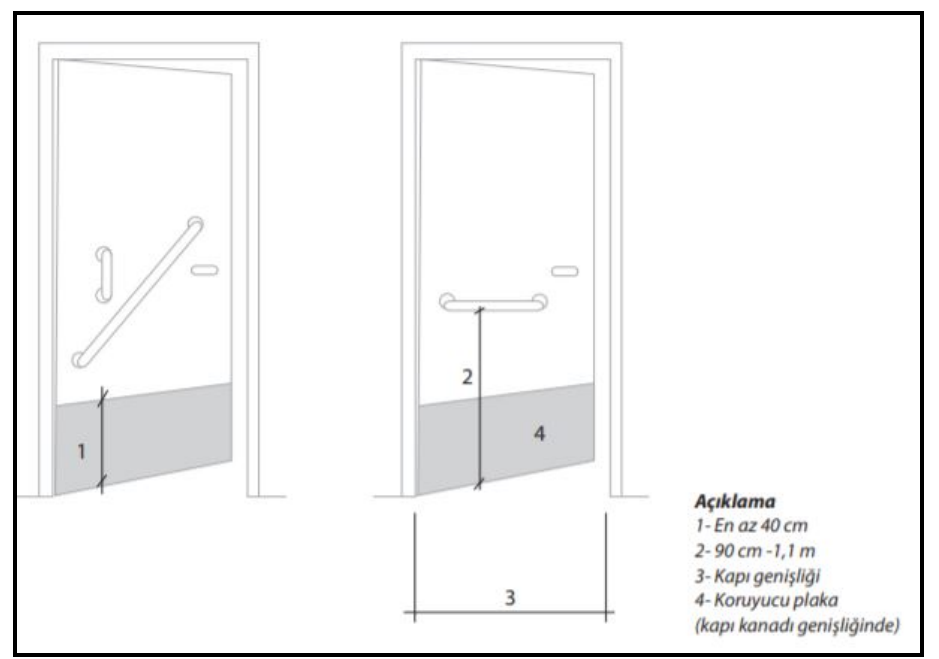

Şekil 15. Koruyucu plaka yerleştirilmiş kapı örnekleri (TS 9111).

Otomatik kapıların dışındaki kapılarda; kendi kendine kapanma mekanizması kullanıldığı durumlarda, bu mekanizmanın kapanmayı geciktiren tipte seçilmesi tavsiye edilir. Bu durum, kapıdan giriş esnasında manevra süresini uzun tutabilmek amacıyla özellikle de sık kullanılan kapılar için yararlıdır. Kapıların açılıp kapanması 22,2 N.'dan fazla kuvvet gerektirmemelidir. Çarpma, yaylı ve döner kapıların, engelli bireylerin kullanımına elverişli olmaması ve tehlike arz edebileceği sebebiyle tercih edilmemelidir. Kapı girişlerinde (önlerinde) uygun manevra alanı oluşturulmalıdır (Şekil 16-17-18-19) (TS 9111). 


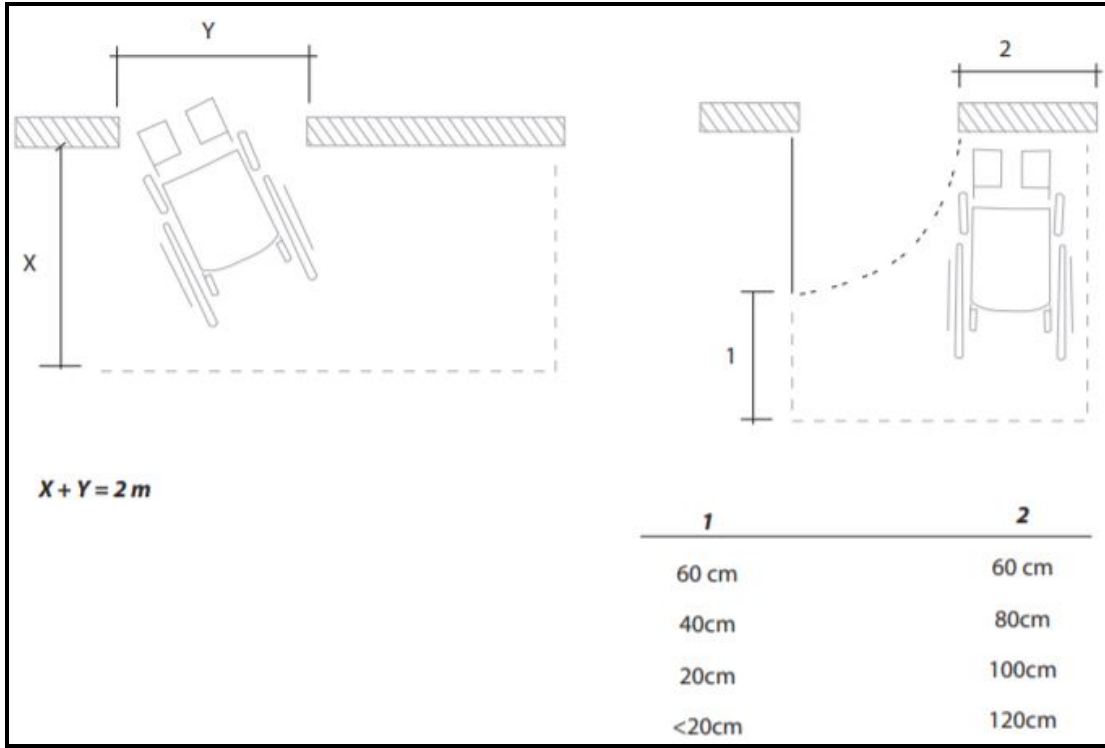

Şekil 16. Uygun manevra alanı oluşturulması için gerekli ölçüler (TS 9111).

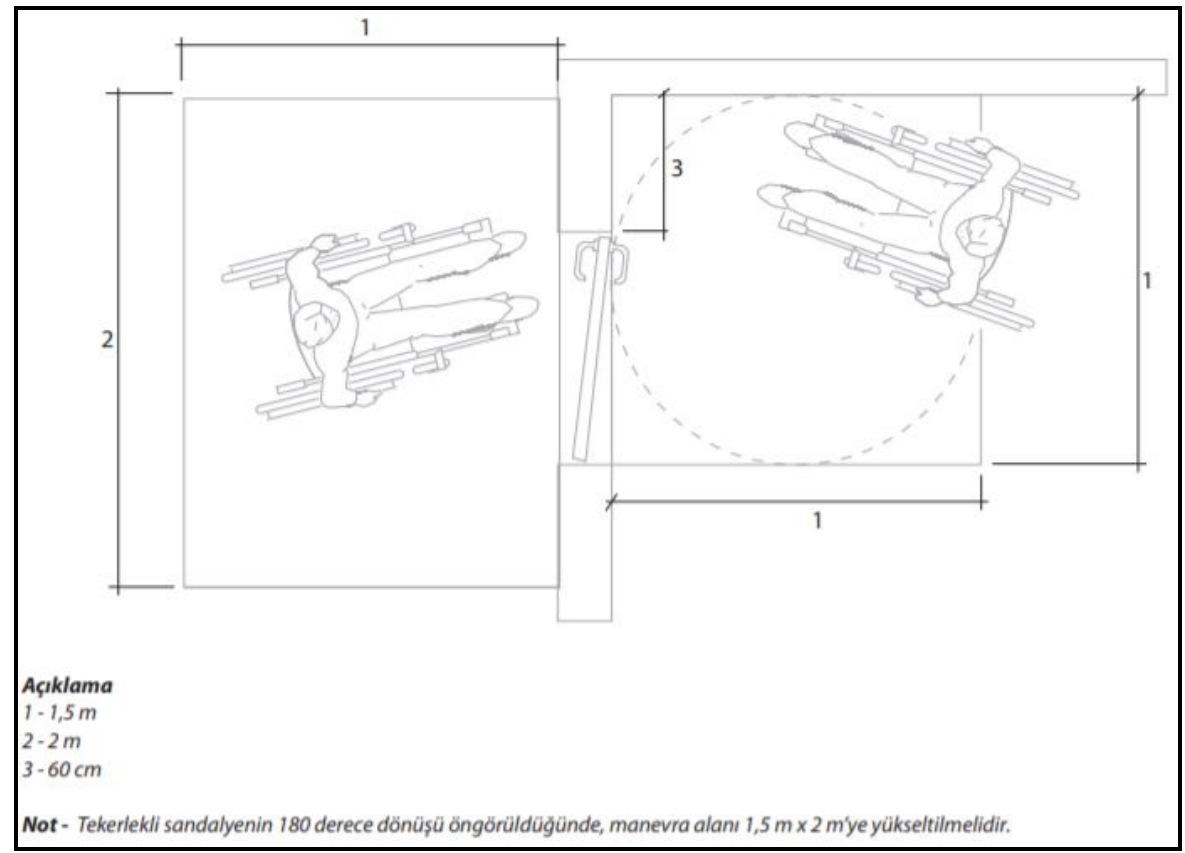

Şekil 17. Menteşeli kapı önünde ve arkasında uygun manevra alanı oluşturulması için gerekli ölçüler (TS 9111). 


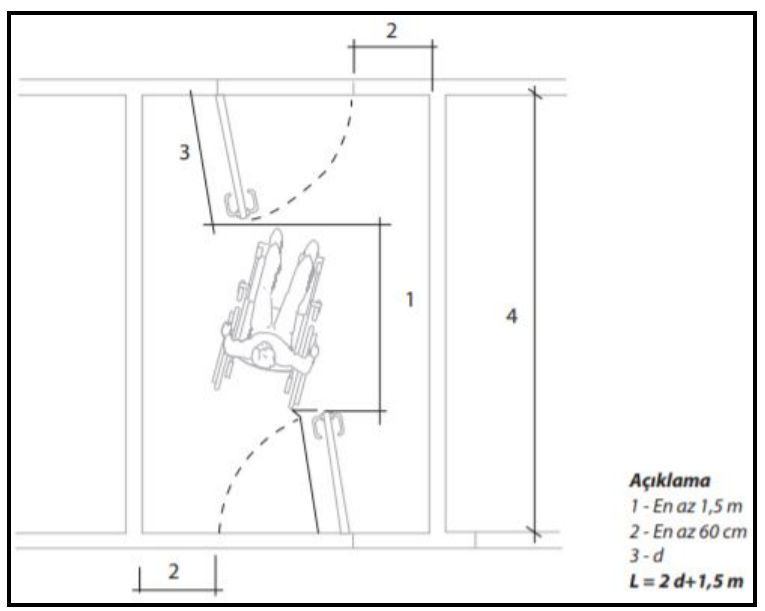

Şekil 18. Kapı önünde uygun manevra alanı oluşturulması için gerekli ölçüler (TS 9111).

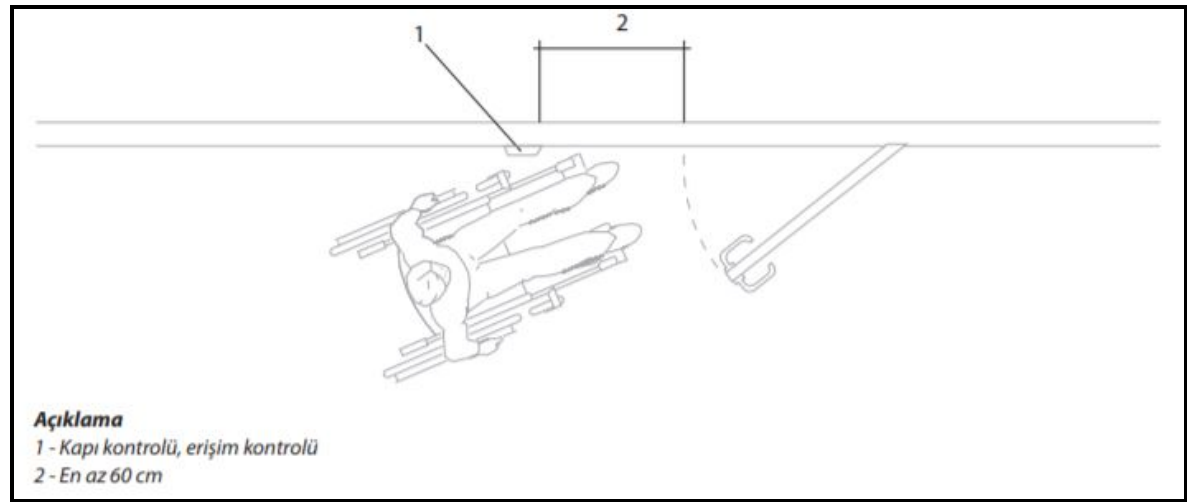

Şekil 19. Kapı önünde uygun manevra alanı oluşturulması için gerekli ölçüler (TS 9111).

Banyo ve tuvalet gibi ayrı bir bölme şeklinde bulunan mekânlarda, alanın darlığı sebebiyle manevra olanağının zor olduğu durumlarda, menteşeli kanatlı kapılar yerine sürme kapılar tercih edilebilir. Katlanabilir kapılar, Şekil 9-c'de gösterildiği şekilde olmalıdır. Zemine yerleştirilen bir temas noktasının kumanda ettiği otomatik kapılar tekerlekli sandalye kullanıcılarının geçişini algılayabilecek nitelikte olmalıdır (TS 9111).

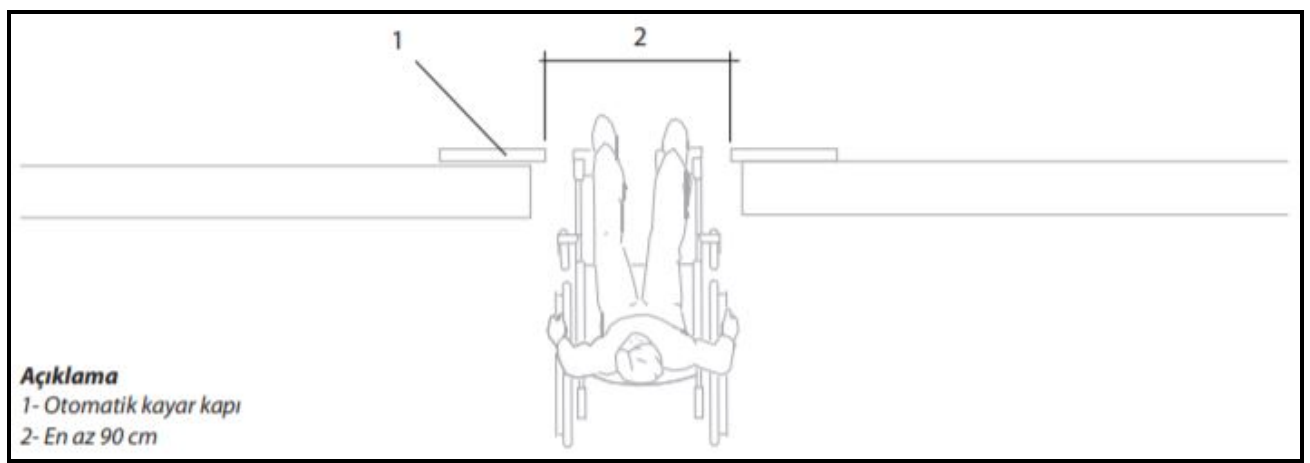

Şekil 20. Otomatik kapı geçiş örneği (TS 9111).

Kapı açıış alanının tekerlekli sandalyeli bireyin manevrasına olanak sağlamadığı takdirde ulaşılabilir ve güvenli konumda yerleştirilmiş olan bir kontrol düğmesi ile kumanda edilerek çalışan kapılar kullanılabilir. Bu kapılar fotoselli (kendiliğinden kapanabilir) özellikte olmalıdır (Şekil 21). 


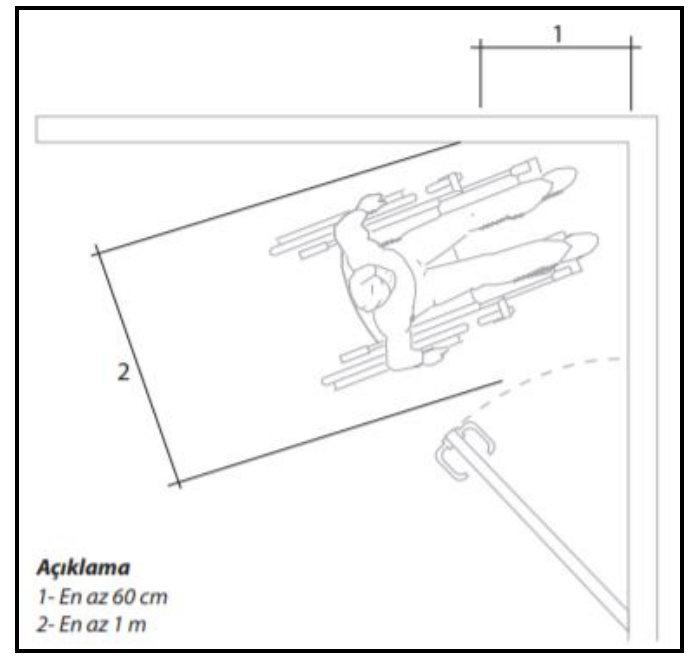

Şekil 21. Kumandalı kapı önünde ve arkasında uygun manevra alanı ve kontrol düğmesi ölçüleri (TS 9111).

\subsection{Lavabo ve Çevresi}

Ayaklı lavabolar tercih edilmemeli ve lavabo altına dolap yerleştirilmemelidir. Tekerlekli sandalye ile her yönden yaklaşımın sağlanması açısından lavaboların köşeli/keskin kenarlı olmaması, oval/yuvarlak hatlı olması gerekmektedir (TS 9111). Tavsiye edilen lavabo ölçüleri aşağıdaki gibidir (Şekil 22).

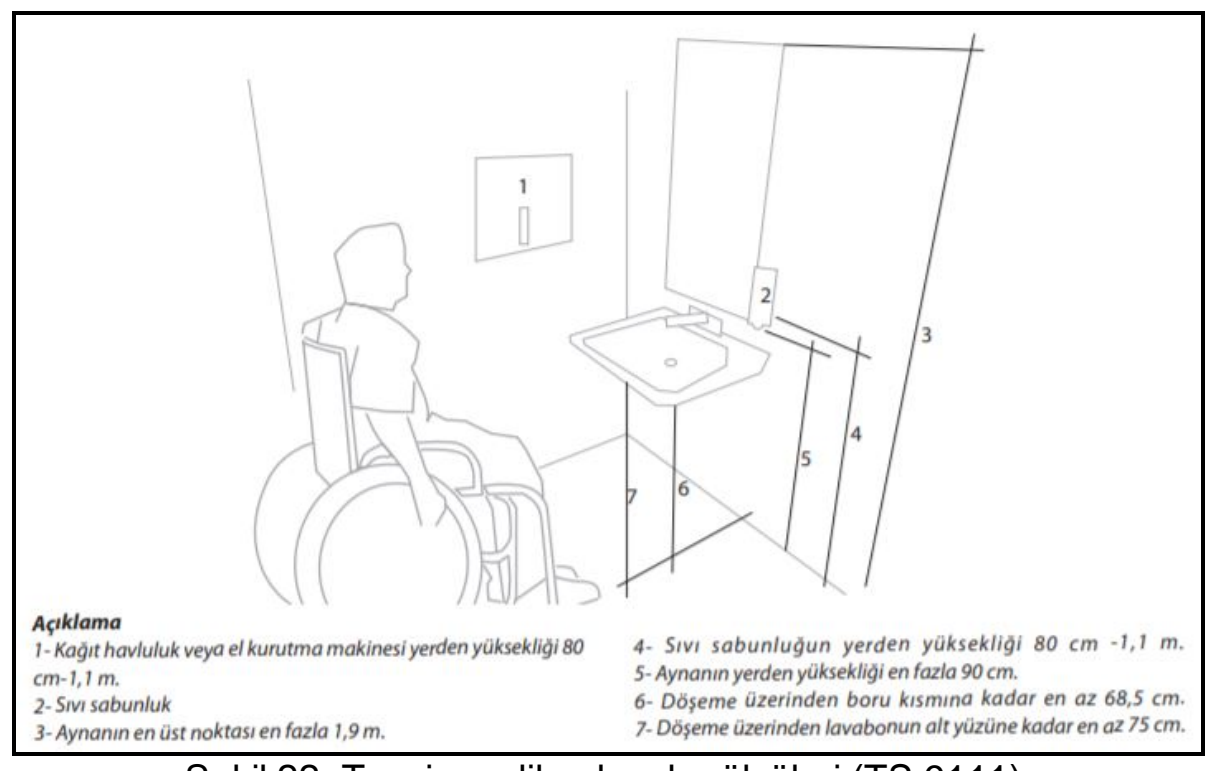

Şekil 22. Tavsiye edilen lavabo ölçüleri (TS 9111).

Lavabonun kullanılabilir olması için lavabo önünde boş bir zemin yüzeyi oluşturulmalı ve lavabo altında gerekli diz boşluğu bırakılmalıdır (Şekil 23). Lavabonun derinliği (ön yüzeyinden arka duvara kadar olan mesafe) $43-49 \mathrm{~cm}$. aralığında olmalıdır. Önden yaklaşımda lavabo önünde $76 \mathrm{~cm}$. x $122 \mathrm{~cm}$. ebatlarında zemin yüzeyi oluşturulmalıdır. Bu zemin yüzeyinin $49 \mathrm{~cm}$. kadarlık kısmı lavabonun altına doğru uzatılabilir (Şekil 23). Diz boşluğu mesafesi, döşeme üzerinden lavabonun altındaki gider borusuna kadar en az $68,5 \mathrm{~cm}$. yüksekliğinde olmalıdır. Aynı zamanda bu yükseklik, lavabonun ön yüzeyinden içeriye doğru en az $20,5 \mathrm{~cm}$. derinlikte de korunmalıdır. Lavabo yüksekliği 
lavabonun alt yüzeyine kadar net en az $75 \mathrm{~cm}$., lavabonun ön üst yüzeyine kadar ise en fazla $86 \mathrm{~cm}$. yükseklikte olmalıdır (Şekil 24) (TS 9111).

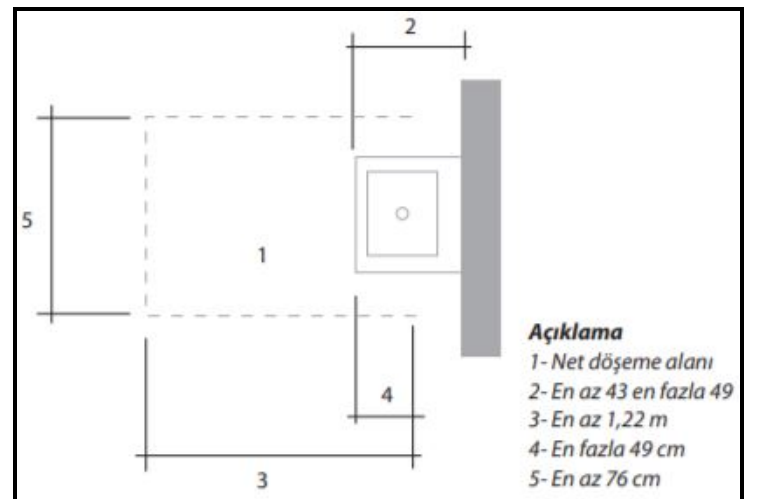

Şekil 23. Tavsiye edilen lavabo önü ölçüleri (TS 9111).

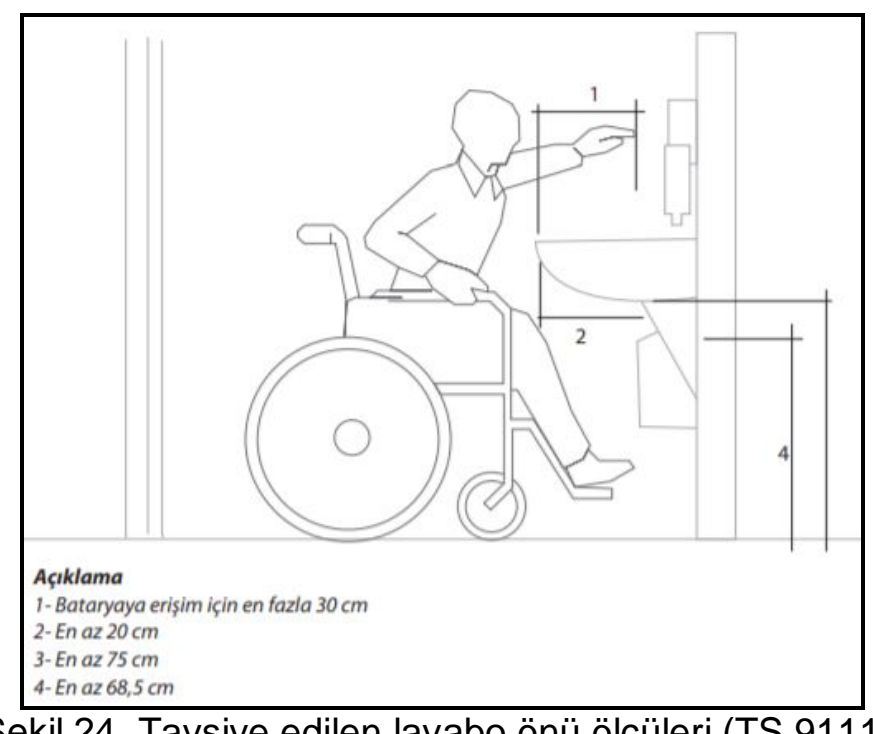

Şekil 24. Tavsiye edilen lavabo önü ölçüleri (TS 9111)

Lavabo armatürleri (musluk/batarya) kollu, itmeli veya elektronik mekanizmalı olmalıdır. Musluklar ve diğer kontrol araçları tek elle ve kolayca kullanılabilir ve 22,2 N.'dan daha fazla güç gerektirmeyecek nitelikte olmalıdır. Ayrıca su çıkışlarının doğru bağlanması gerekmekte ve sıcak su kontrolü sol, soğuk su kontrolü ise sağ tarafta yer almalıdır (TS 9111).

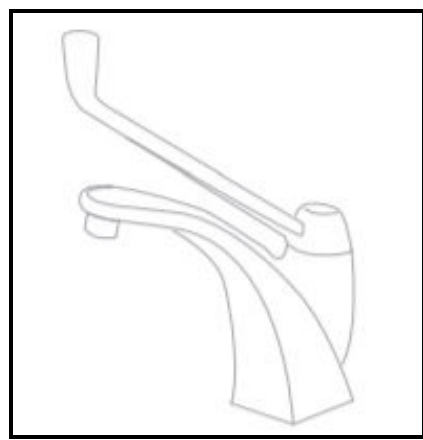

Şekil 25. Kullanılabilir musluk örneği (TS 9111). 
Eğer fotoselli tipte musluk tercih edilir ise en az 10 saniye açık kalabilmelidir. El yıkama sırasında el ile lavabo arasındaki mesafenin rahat kullanılabilir şekilde olması açısından armatür tercihinde bu konu göz önüne alınmalıdır. Lavabo altındaki gider borularına yalıtım uygulanmalı veya dokunmaya karşı önlem alınmalıdır. Lavabo altında keskin, sivri veya rahatsız edici yüzeyler oluşturulmamasına özen gösterilmelidir. Ayrıca lavabonun her iki yanına ayakta durmakta zorlanan bireyler için tutunma çubukları yerleştirilmelidir (Şekil 26).

Lavabo aynalarının alt kotu döşeme üzerinden en fazla $90 \mathrm{~cm}$., üst kotu ise en fazla $190 \mathrm{~cm}$. yüksekte olmalıdır. Tekerlekli sandalye kullanıcısının göz hizasının yerden yüksekliği $110-130 \mathrm{~cm}$. aralığındadır. Tekerlekli sandalye kullanıcıları için alçalıp yükselebilen ayarlı aynalar ya da aynanın sabit olması durumunda öne doğru $10^{\circ}-15^{\circ}$ eğim verilmiş aynalar kullanılması önerilmektedir (TS 9111).

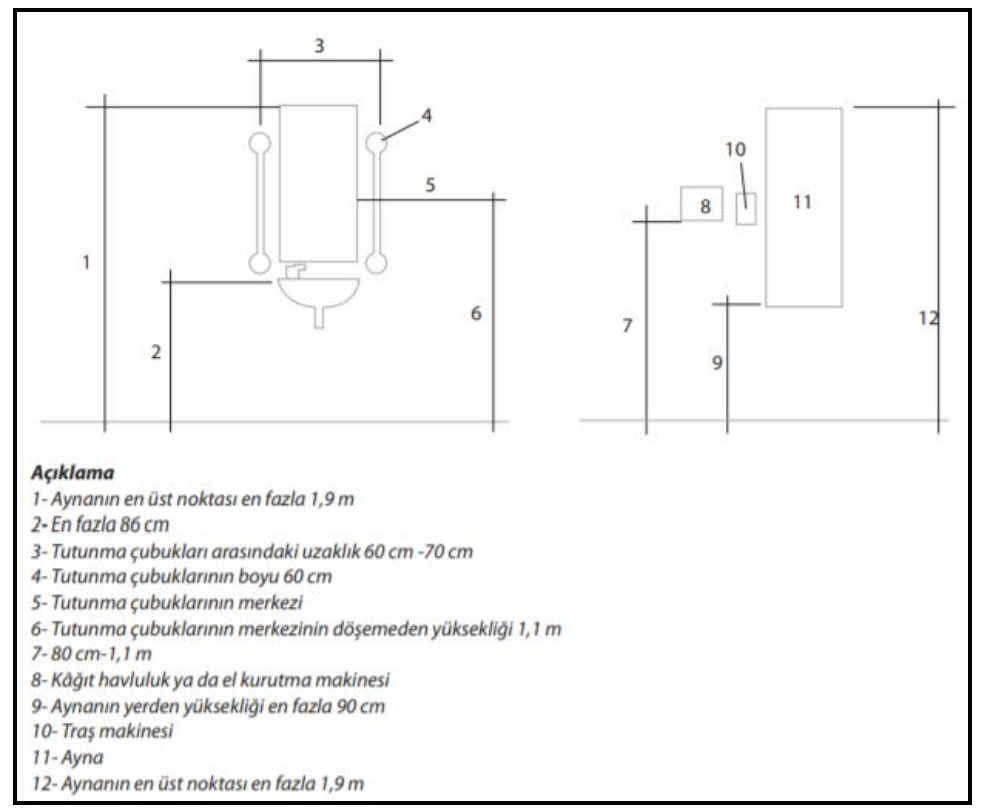

Şekil 26. Tavsiye edilen lavabo çevresi ölçüleri (TS 9111).

\subsection{Klozet ve Çevresi}

Klozetlere yaklaşımda, zemindeki asgari zemin yüzeyi sol taraftan veya sağ taraftan yaklaşıma uygun şekilde düzenlenebilir. Banyo kapısının dışa açılması koşulu ile asgari net zemin yüzeyi ebatları, önden yaklaşım için (düz transfer durumunda) 122 cm. x $1675 \mathrm{~cm}$.; sağ yandan yaklaşımda (diyagonal transfer durumunda) $122 \mathrm{~cm}$. x 142 $\mathrm{cm}$. ve hem ön hem sol yandan yaklaşımda (yan transfer durumunda) $150 \mathrm{~cm}$. x 142 $\mathrm{cm}$. ebatlarında olmalıdır. Banyolarda klozet kullanılmalıdır ve klozetin konumlandırılmasında orta aksın yan duvardan uzaklığının en az $46 \mathrm{~cm}$., toplamda klozetin yerleştirildiği alanın net genişliğinin ise en az $92 \mathrm{~cm}$. olmasına dikkat edilmelidir (TS 9111). Farklı plan tiplerinde konumlandırılan klozet için ölçüler Şekil 27'de verilmiştir. 


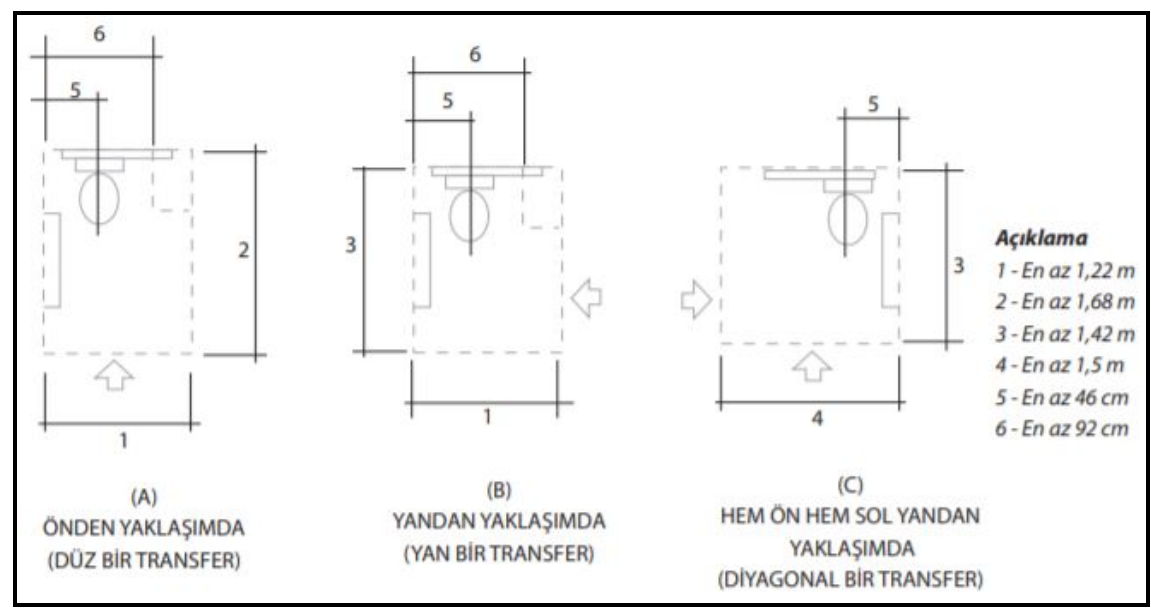

Şekil 27. Tavsiye edilen klozet ölçüleri (TS 9111).

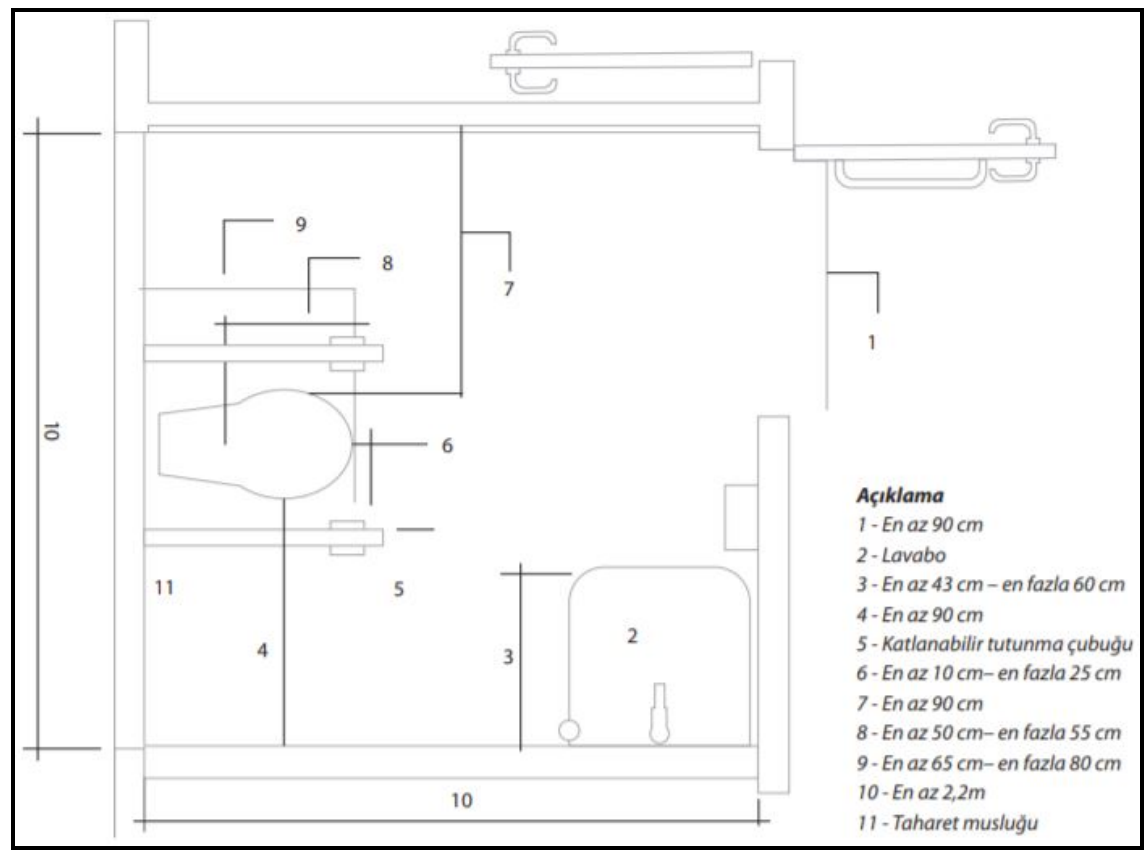

Şekil 28. Klozete her iki taraftan yatay transfer için gerekli ölçüler (TS 9111).

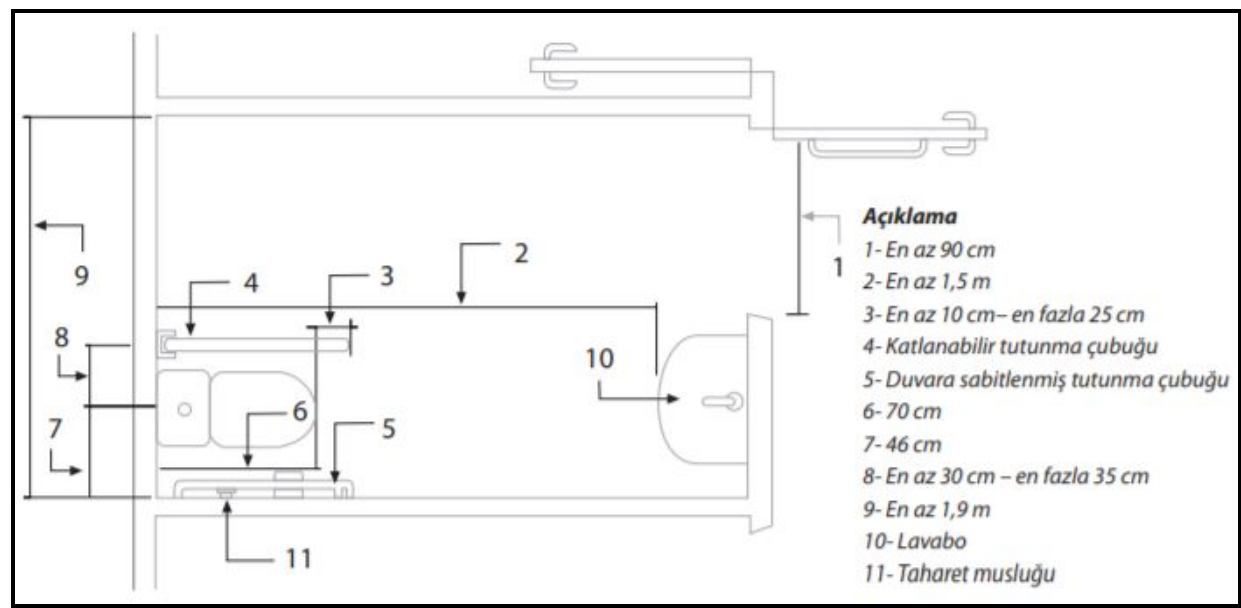

Şekil 29. Klozete tek taraftan yatay transfer için gerekli ölçüler (Geniş alanda) (TS 9111). 


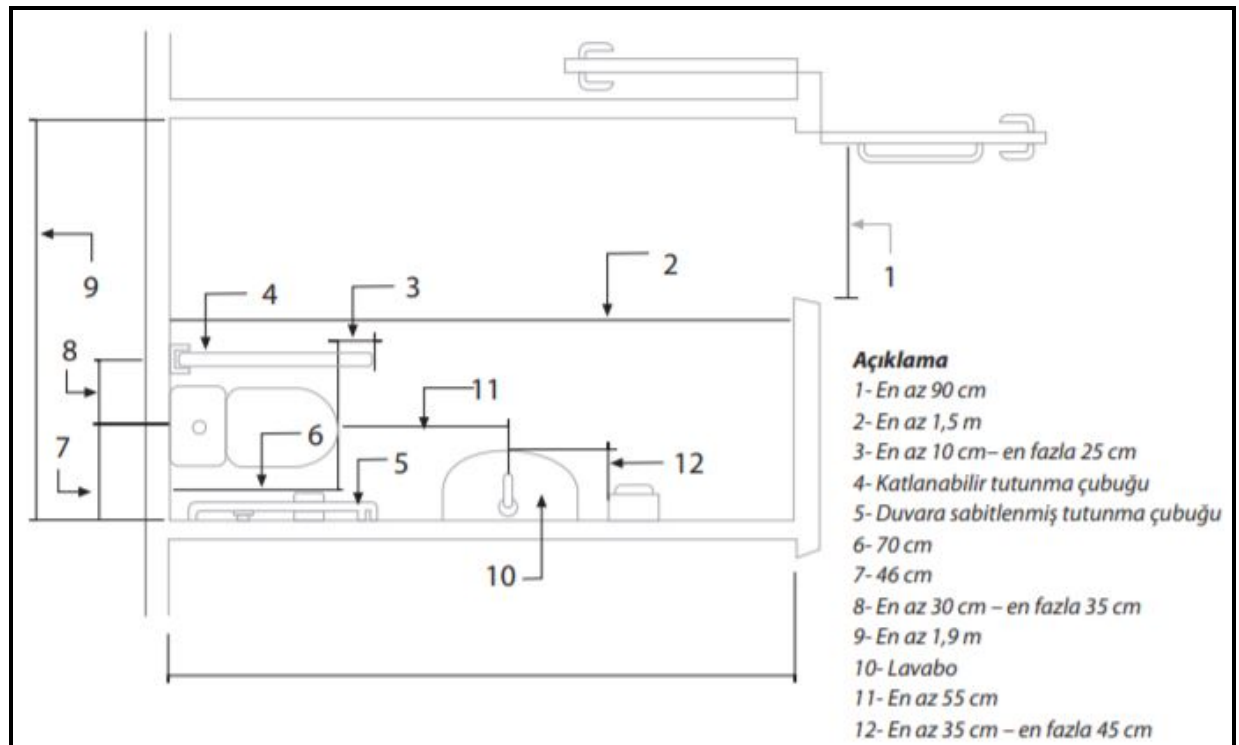

Şekil 30. Klozete tek taraftan yatay transfer için gerekli ölçüler (dar alanda) (TS 9111). Klozetlerin oturma kısımlarının yerden yüksekliği 43-48 cm. aralığında olmalıdır. Oturma yüksekliğinin ayarlanabilir olması için klozetin adaptör takılabilecek tipte seçilmesi tavsiye edilir (TS 9111).

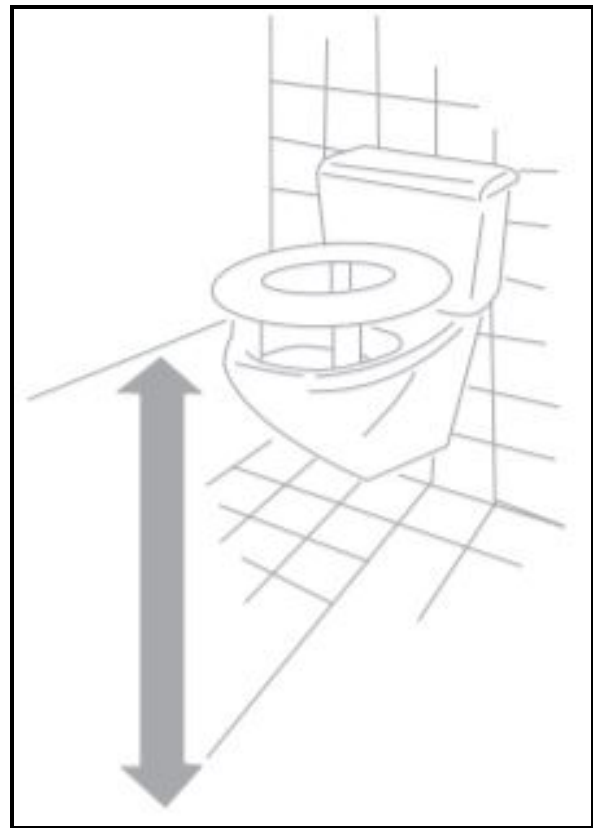

Şekil 31. Yüksekliği ayarlanabilen adaptör monte edilmiş klozet (TS 9111).

Klozet, tekerlekli sandalyeden transfere olanak sağlayacak şekilde konumlandırılmalıdır (TS 9111). Klozet çapraz ve yan yaklaşım, alternatif ve ölçüleriyle Şekil 32'de verilmiştir. 

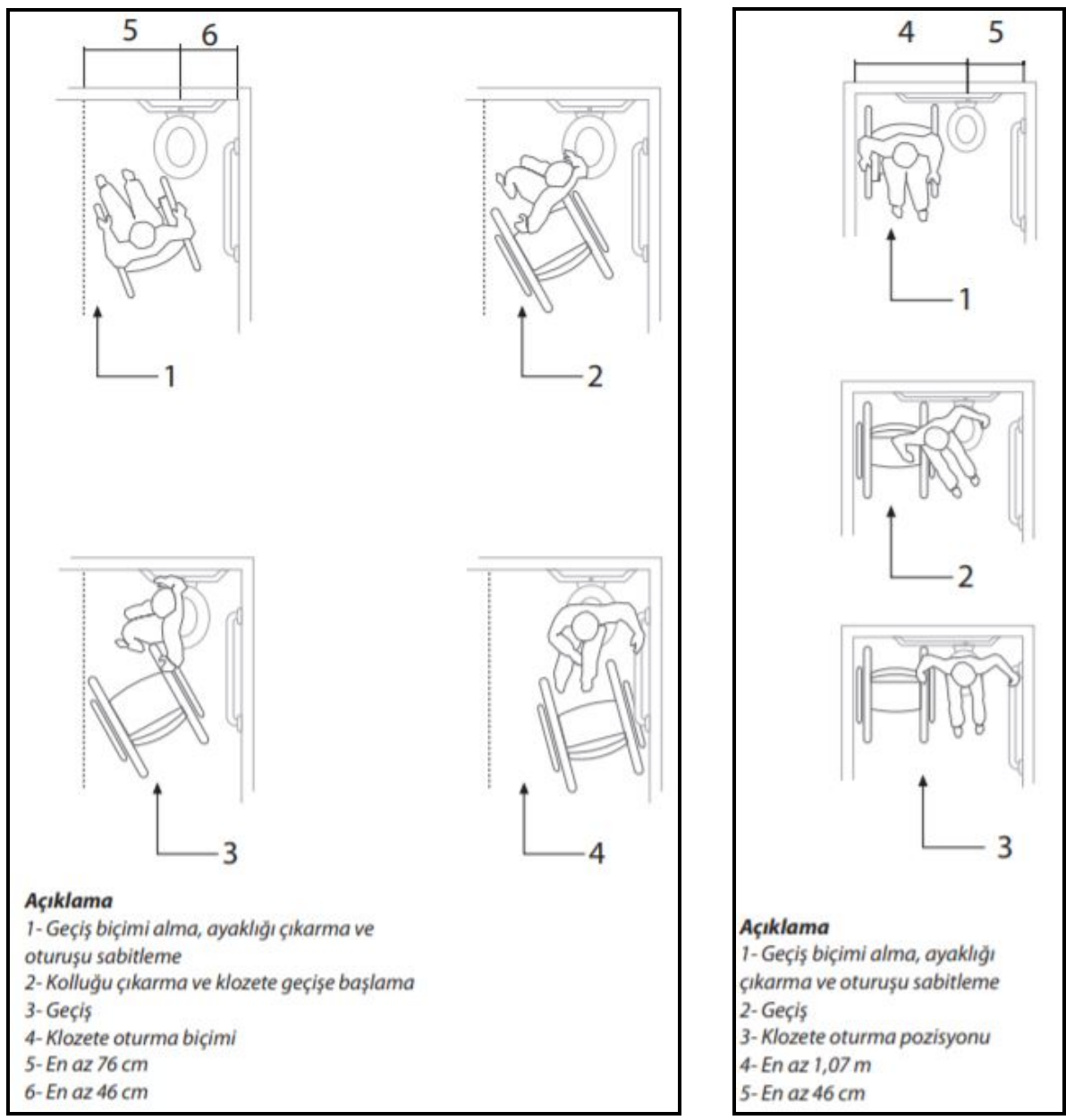

Şekil 32. Klozete çapraz ve yan yaklaşım (TS 9111).

Genel olarak fotoselli sifon kolu kullanımı tavsiye edilmesinin yanı sıra el ile kumandalı veya otomatik sifon kolu da kullanılabilir. Bu kollar tek elle kolayca ve 22,2 N.'den daha fazla kuvvet gerektirmeden kullanabilmeye uygun olmalıdır. Sifon kolu yerden en fazla $112 \mathrm{~cm}$. yükseklikte olmalıdır. Taharet muslukları tek elle kolay kullanıma uygun ve yeterli erişim mesafesinde olmalıdır. Tuvalet kâğıtı̆̆ı kolayca ulaşılabilir yükseklikte ve konumda bulunmalıdır. Arka duvara monte edilmiş bir klozetin tuvalet kâğıtığının arka duvardan olan mesafesi $90 \mathrm{~cm}$.'yi geçmemelidir (TS 9111). 


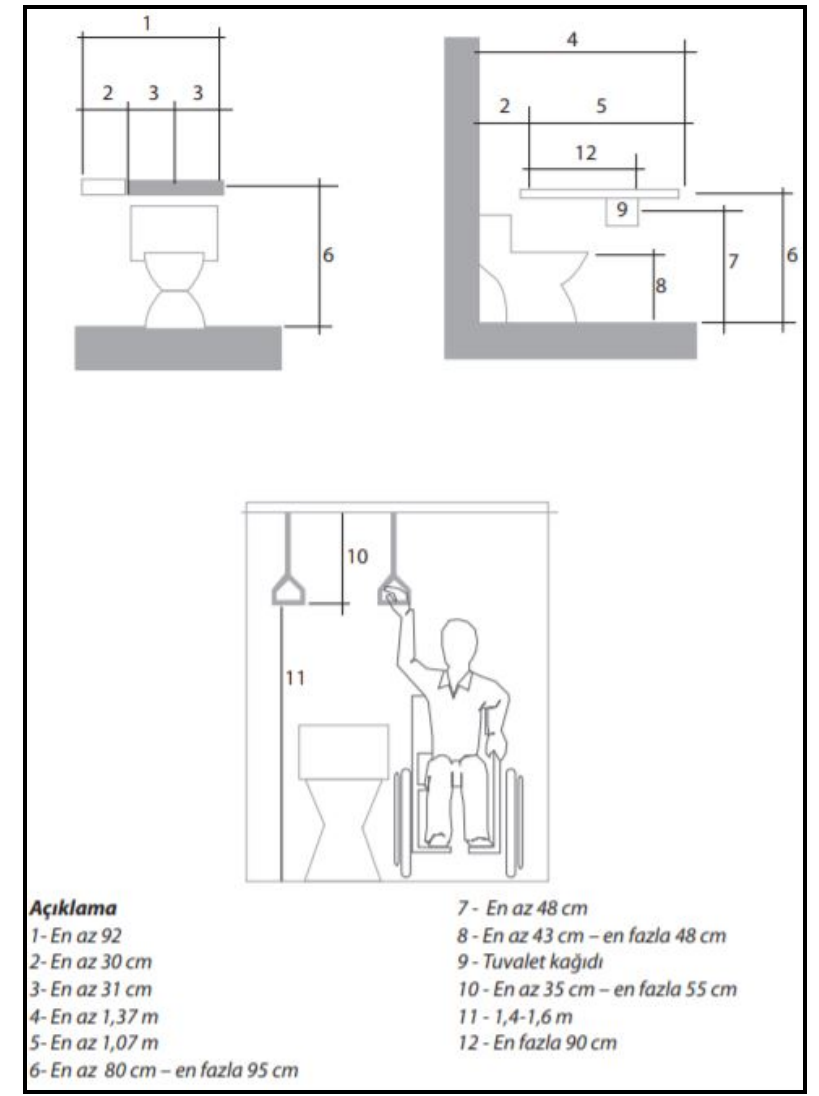

Şekil 33. Klozet çevresi (tutunma çubukları ve tuvalet kâğıtlı̆̆ı) (TS 9111).

Tutunma çubuklarının çapı 3,2-3,8 cm. aralığında olmalıdır (El ile kolayca kavranabilmesi açısından). Duvara monte edilmesi durumunda, duvarla tutunma çubuğu arasında $4 \mathrm{~cm}$. mesafe bulunmalıdır. Klozetin arka duvarındaki tutunma çubuğu $80-95 \mathrm{~cm}$. arası yükseklikte olmalıdır. Klozet arkasında duvarda yer alan tutunma çubuğu en az $92 \mathrm{~cm}$. uzunluğunda olmalıdır. Tutunma çubuğu klozetten sağ veya sol yana doğru en az $30 \mathrm{~cm}$. mesafede uzamalıdır (TS 9111).

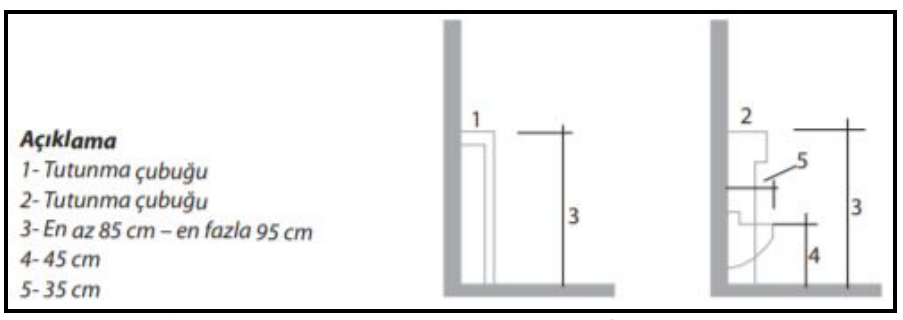

Şekil 34. Pisuar ölçüleri (TS 9111).

Pisuarlar, ayrı bir bölme şeklinde veya döşeme üzerinden en fazla $45 \mathrm{~cm}$. yükseklikte olacak şekilde, uzun kenarından duvara asılı bir şekilde yerleştirilmelidir. Önden yaklaşım açısından pisuarların önünde $76 \mathrm{~cm}$. x $122 \mathrm{~cm}$. ebatlarında boş alan oluşturulmalıdır ve oluşturulan bu alan ulaşılabilir güzergâh ile çakışabilir. Pisuar bölmeleri pisuar kenarından daha öne uzatılmamalıdır. Bu durumda pisuar kenarları arasındaki net mesafe $74 \mathrm{~cm}$. olarak belirlenebilir (TS 9111). 


\subsection{Yıkanma Birimi ve Çevresi}

\section{Küvet Birimi}

Küvet önü net kullanım alanı, banyoda yer alan çeşitli donanımlara ve plan tiplerine göre Şekil 3.91, 3.92., 3.93. ve 3.94.'e uygun olmalıdır. Küvete paralel yaklaşımda; net en az $76 \mathrm{~cm}$. genişlik ve küvet boyunca net en az $150 \mathrm{~cm}$. uzunlukta alan oluşturulması gerekmektedir. Küvete dik yaklaşımda; uygun mesafe varsa net en az $122 \mathrm{~cm}$. genişlik ve net en az $150 \mathrm{~cm}$. uzunlukta alan oluşturulması gerekmektedir. Küvetin baş kısmında oturma yeri/oturak bulunuyorsa paralel yaklaşımda; en az genişlik $76 \mathrm{~cm}$. ve en az $190 \mathrm{~cm}$. uzunlukta alan oluşturulmalıdır (Şekil 35). Küvetin döşeme üzerinden net yüksekliği en fazla $45-50 \mathrm{~cm}$. aralığında olmalıdır. Küvet kullanılan durumlarda kenarı açılıp kapanabilen özel küvetler tercih edilebilir. Ayrıca küvet tabanı kademeli olmamalıdır (TS 9111).

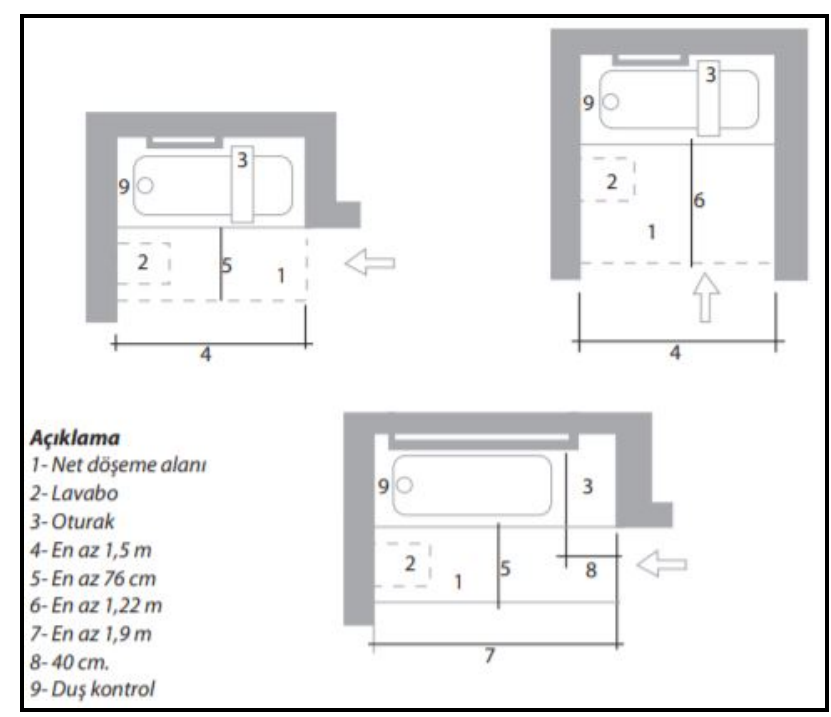

Şekil 35. Küvet önü net kullanım alanı ölçüleri (TS 9111).

Küvetin içinde oturak varsa; küvetin ayak kısmında, dış kenardan itibaren en az $60 \mathrm{~cm}$. uzunluğunda bir tutunma çubuğu bulunmalıdır. Arka duvarda ise iki tutunma çubuğu gereklidir. Küvetin uzun tarafına monte edilen tutunma çubukları en az $61 \mathrm{~cm}$. uzunluğunda ve küvetin baş kısmından en fazla $61 \mathrm{~cm}$. mesafede, ayak kısmından da en fazla $30 \mathrm{~cm}$. mesafede yer almalıdır. Bir tutunma çubuğu, küvet kenarından $23 \mathrm{~cm}$. yükseğe monte edilmelidir. Diğer çubuklar ise banyo döşemesi üzerinden $84-91 \mathrm{~cm}$. arası yükseklikte konumlandırılmalıdır. Küvetin baş kısmına yerleştirilen tutunma çubuğu, küvetin dış kenarından en az $30 \mathrm{~cm}$. mesafede bulunmalıdır (TS 9111).

Küvetin baş kısmında oturma yeri varsa; küvetin ayak kısmında küvetin dış kenarından en az $60 \mathrm{~cm}$. mesafede yerleştirilmiş tutunma çubuğu olmalıdır. Arka duvarda, iki tutunma çubuğu bulunmalıdır. Küvetin uzun tarafına monte edilen tutunma barları en az $122 \mathrm{~cm}$. uzunluğunda olmalı ve küvetin baş kısmından en fazla $38 \mathrm{~cm}$., ayak kısmından ise en fazla $30 \mathrm{~cm}$. mesafede yer almalıdır. Çubukların yükseklikleri yukarıda açıklandığı şekildedir. Tutunma barlarının yeri ve yerden yükseklikleri Şekil 36 ve Şekil 37.'ye uygun olmalıdır (TS 9111). 


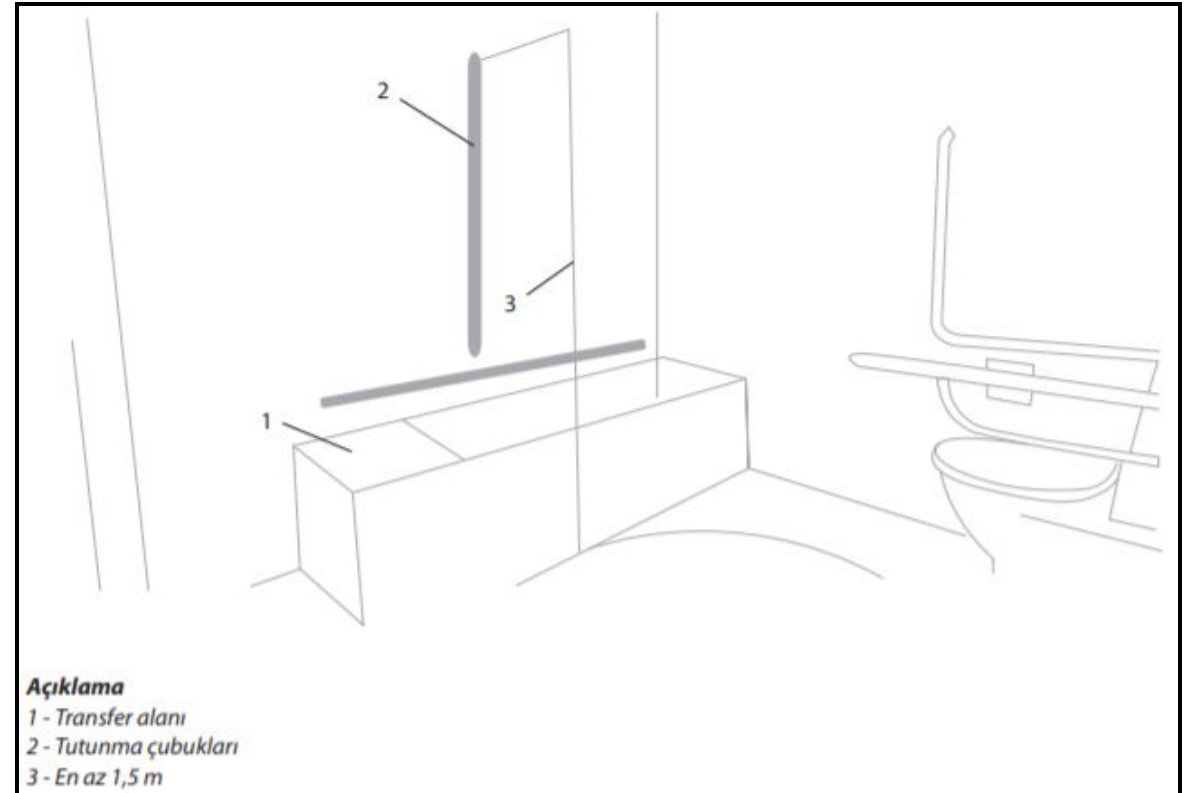

Şekil 36. Tutunma çubuklarının ve su kontrolünün konum ve ölçüleri (TS 9111).

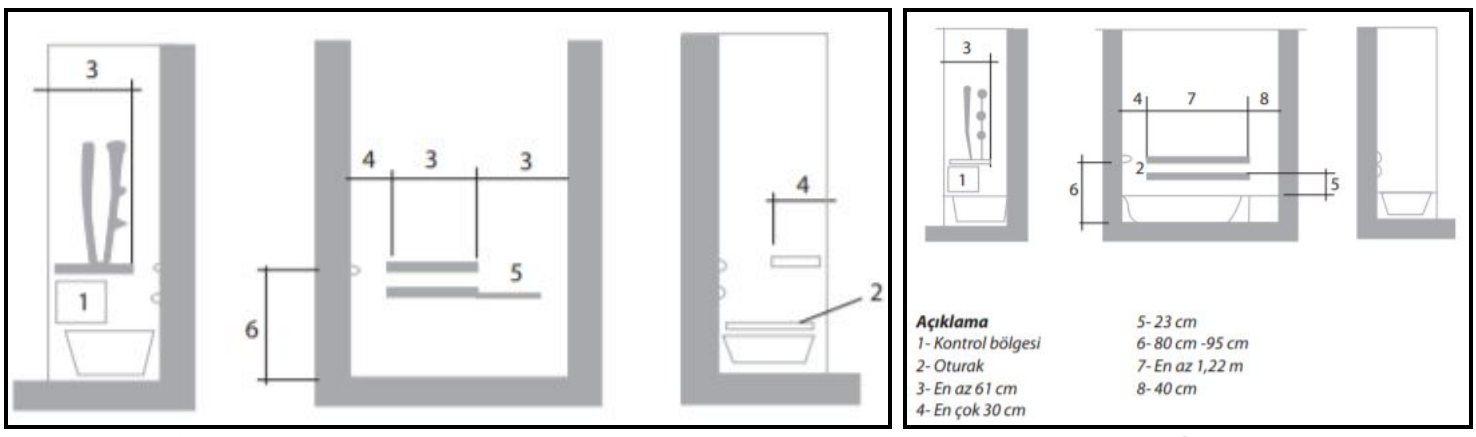

Şekil 37. Tutunma çubukları, su kontrol ve oturak ölçüleri (TS 9111).

Küvet içerisine hareketli bir oturma aparatı yerleştirilmeli veya küvetin kenarında oturma için gerekli alan bırakılmalıdır. Oturma kısmının genişliği $40 \mathrm{~cm}$. olmalı ve küvetin genişliği kadar uzanmalıdır. Oturma aparatı güvenli ve sağlam olacak şekilde monte edilmeli, kullanım esnasında tehlike arz edecek durumlara yol açmamalıdır. Küveti sınırlayan paneller mevcutsa, kontrollere, küvete giriş çıkışa ve oturakların kullanımına engel olmamalıdır. Küveti sınırlayan panellerde, küvet kenarına monte edilmiş raylar bulunmamalıdır. Tekerlekli sandalye kullanıcılarının rahat bir şekilde oturabilmesi için küvetin uzun kenarının et kalınlığı 8-12 cm. arasında olmalıdır ve ayrıca vücudu kesecek şekilde keskin hatlara sahip olmamalıdır (TS 9111).

\section{Duş Birimi}

Duş kabinleri ebatları en az $95 \mathrm{~cm}$. x $95 \mathrm{~cm}$. veya $76 \mathrm{~cm}$. x $150 \mathrm{~cm}$. olmalıdır (Şekil 38,39 ve 40 ). $95 \mathrm{~cm}$. x $95 \mathrm{~cm}$. ebatlarına sahip bir duş teknesine paralel yaklaşımda; duş teknesi önünde en az $90 \mathrm{~cm}$. genişlik ve en az $122 \mathrm{~cm}$. uzunluğunda bir alan oluşturulmalıdır. $76 \mathrm{~cm}$. x $150 \mathrm{~cm}$. ebatlarına sahip bir duş teknesinin ise önünde duş teknesi boyunca en az $150 \mathrm{~cm}$. ve genişliği en az $90 \mathrm{~cm}$. olan bir alan oluşturulmalıdır (Şekil 38-39) (TS 9111). 


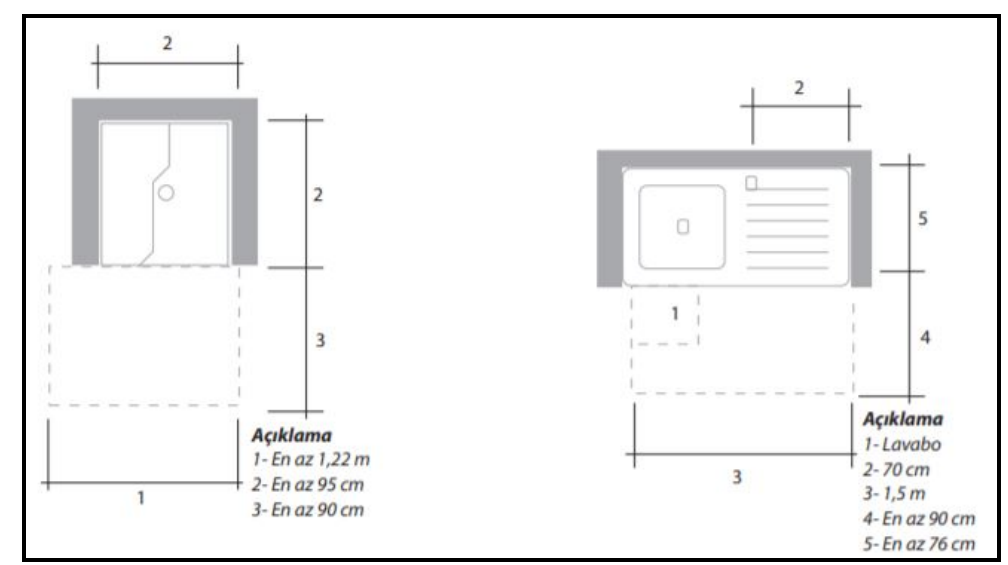

Şekil 38. Banyo ve duş kabinine dair ölçüler (TS 9111).

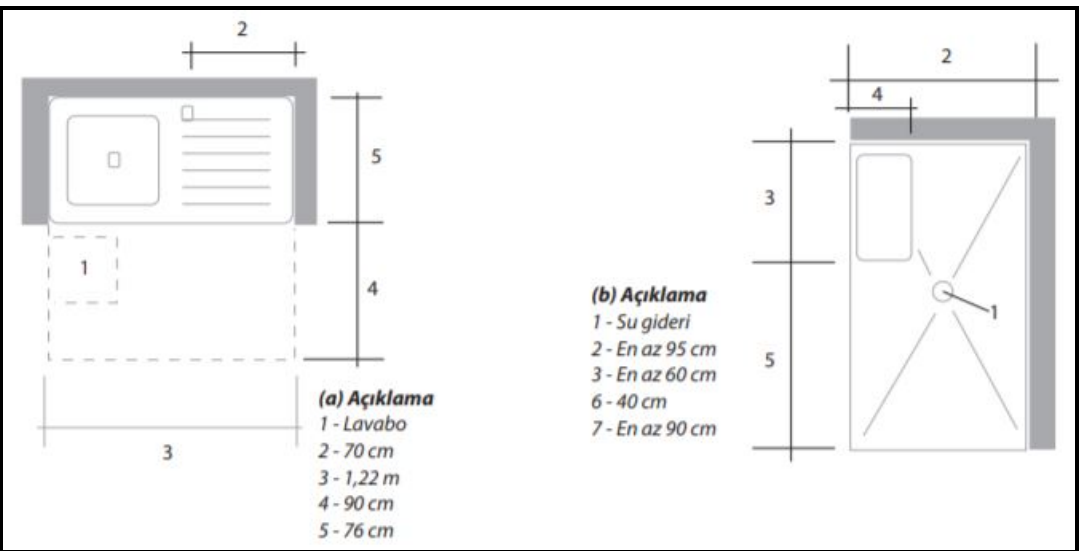

Şekil 39. Banyo ve duş kabinine dair ölçüler (TS 9111).

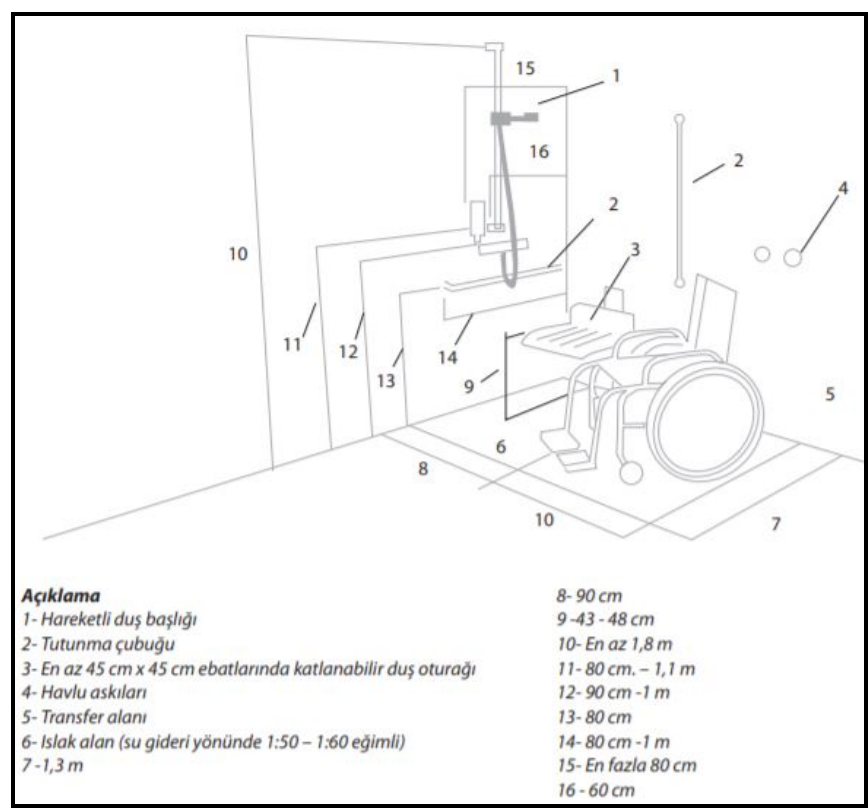

Şekil 40. Duş teknesine dair ölçüler (TS 9111).

Tutunma çubukları, duş zemininden itibaren 80 - $95 \mathrm{~cm}$. aralığında bir yüksekliğe monte edilmelidir. Tutunma çubuklarının duvara monte edilmesi durumunda duvar ile tutunma çubuğu arasında $4 \mathrm{~cm}$. mesafe bırakılmalıdır. Tutunma çubuklarının çapı ise $3,2-4 \mathrm{~cm}$. aralığında tutulmalıdır. $95 \mathrm{~cm}$. x $95 \mathrm{~cm}$. ebatlarında bir duş teknesinde 
oturağın karşı tarafında su kontrollerin (bataryanın) yer aldığı duvar boyunca ve arka duvarın yarısı boyunca $L$ biçiminde bir tutunma çubuğu yerleştirilmelidir. $76 \mathrm{~cm}$. x 150 $\mathrm{cm}$. boyutlarında dikdörtgen bir duş teknesinde ise duş teknesini çevreler konumda $U$ şeklinde tutunma çubukları yerleştirilmelidir (Şekil 38). $76 \mathrm{~cm} . \times 150 \mathrm{~cm}$. ebatlarında dikdörtgen bir duş teknesi tercih edilmesi ve katlanabilir oturak düşünülmesi durumunda da tutunma çubukları Şekil 39 ve 41'e göre düzenlenmelidir (TS 9111).

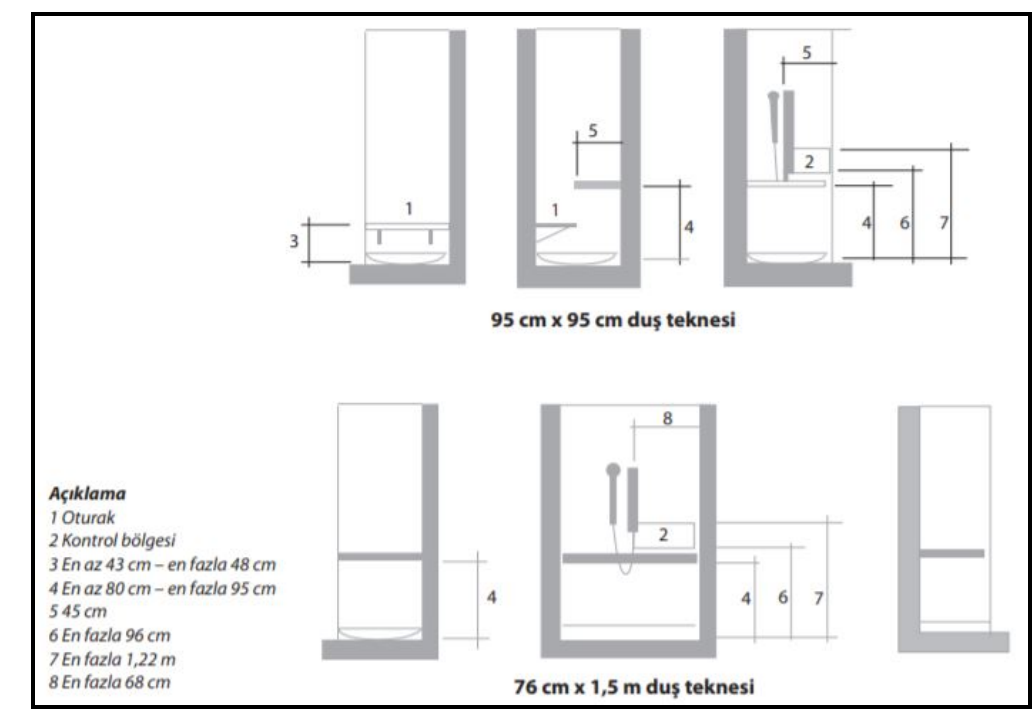

Şekil 41. Duş bölmesi ve birimlerine dair ölçüler (tutunma çubukları, su kontrolü ve oturak) (TS 9111).

Duş başlığının hortumu en az $160 \mathrm{~cm}$. uzunluğunda olup, gerek sabit duş başlığı gerekse elle tutulur şekilde kullanmaya uygun olmalıdır. Düşey hizada bir çubuk üzerine monte edilmiş ve yüksekliği ayarlanabilir bir duş başlığı kullanılması durumunda; düşey çubuğun, yanlarda paralel bir biçimde yerleştirilmiş tutunma çubuklarının kullanımına engel teşkil etmeyecek şekilde yerleştirilmesi gerekmektedir. Bunlara ilaveten suyun sıcaklık derecesi termostatla kontrol edilebilir durumda olmalıdır. $95 \mathrm{~cm}$. x $95 \mathrm{~cm}$. ebatlarında bir duş biriminde duş birimi derinliğince oturak düşünülmelidir. Bu oturağın döşeme üzerinden yüksekliği $43-48,5 \mathrm{~cm}$. aralığında, yan ve arka duvarlardan ise en fazla $3,8 \mathrm{~cm}$. mesafede olmalıdır. "L" biçimindeki oturağın yan tarafa uzanan kısmının yan duvardan olan mesafesi en fazla $38 \mathrm{~cm}$., eninin ise arka duvardan itibaren 60 cm.'yi aşmaması gerekmektedir (Şekil 42). $76 \mathrm{~cm}$. x $150 \mathrm{~cm}$. ebatlarında bir duş biriminde oturak ve su kontrollerinin bağlantısı Şekil 41'deki gibi olmalıdır (TS 9111).

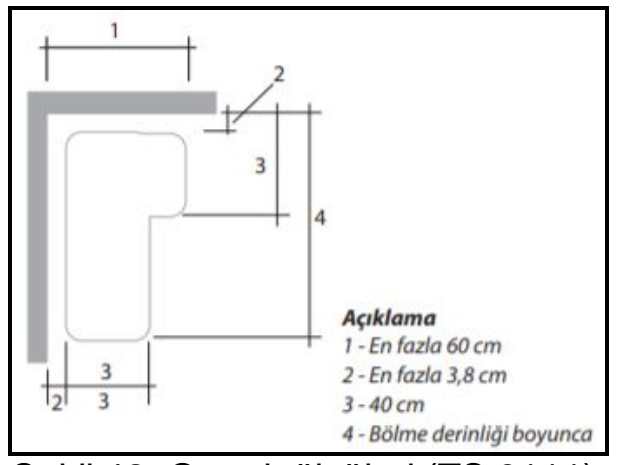

Şekil 42. Oturak ölçüleri (TS 9111). 
$95 \mathrm{~cm} . \times 95 \mathrm{~cm}$. ebatlarında bir duş biriminde koruma bordürü düşünülmüş ise bordürün yüksekliği en fazla $1,3 \mathrm{~cm}$. olmalıdır. $76 \mathrm{~cm}$. x $150 \mathrm{~cm}$. ebatlarında bir duş biriminde ise koruma bordürü yapılmasına intiyaç yoktur. Ayrıca sudan korunma yöntemi olarak duş kabini veya duş perdesi düşünülmüş ise, tekerlekli sandalye kullanıcısının oturağa ve su kontrollerine erişime engel olmamalıdır (TS 9111).

\subsection{Zemin Döşeme Malzemesi}

Banyoların zemin döşeme malzemesi tekerlekli sandalyenin hareketine engel olmayacak ve seviye farkı oluşturmayacak şekilde düzenlenmelidir. Girişte seviye farkı varsa $0,6 \mathrm{~cm}$.'den fazla olmamalıdır. $0,6-1,3 \mathrm{~cm}$. arasındaki seviye farklılıkları $1 / 2$ 'den fazla olmayan bir eğimle birleştirilmelidir. Banyo giderleri kapı önünde su birikmesini önleyecek şekilde tasarlanmalı ve zemin döşeme yüzeyleri kaymayan (ıslak/kuru) özellikte olmalıdır (TS 9111).

\section{MATERYAL VE YÖNTEM}

\subsection{Amaç}

Çalışmanın ana materyalini İstanbul İli Pendik İlçesi'nde yer alan A, B ve C otelleri oluşturmaktadır. Her üç şehir içi otelinde de araştırma; otel odaları bünyesindeki banyolar üzerinden yürütülmüştür. Çalışmanın yardımcı materyalini ise konuyla ilgili yapılan çeşitli plan ve projeler, yurt dışında engellilere yönelik iç mekân kullanımıyla ilgili standartlar, Türk Standardları Enstitüsü tarafından engelliler için oluşturulmuş standartlar, konuyla ilgili araştırmalar, makaleler ve tezler oluşturmaktadır.

\subsection{Kapsam}

Konum özellikleri nedeniyle çalışma alanı olarak seçilen Pendik bölgesi; barındırdığı ulaşım, turizm, sosyal ve kültürel olanakları sebebiyle hızla farklılaşmaktadır. Havalimanı, teknopark, uydukent gibi önemli yapıların bulunması, bu yapıların seyahate alt yapı sağlaması ve herkesin olduğu gibi bedensel engelli bireylerin de seyahat hakkı olması konaklama ihtiyacını beraberinde getirmektedir. Bu intiyaç dahilinde çalışma kapsamında ele alınan üç otelin ortak noktaları; lokasyon itibariyle aynı bölgede yer almaları, bünyelerinde engelli odaları bulundurmaları ve hizmet kalitesi açısından eşit yıldız sayısına (5 yıldızı) sahip olmalarıdır. Pendik İlçesi'nde bulunan toplam 15 adet otelin, 4 tanesi 5 yıldızlı statüye sahiptir (Türob, 2020). Bu 4 otelden incelemeye alınan 3 tanesine ilişkin genel bilgiler aşağıdaki gibidir:

Çizelge 1: Otellere Ait Genel Bilgiler

\begin{tabular}{|l|l|l|l|}
\hline OTELIN ADI & A OTELI & B OTELI & C OTELI \\
\hline OTELIN SINIFI & 5 Yıldızlı & 5 Yıldızlı & 5 Yıldızlı \\
\hline $\begin{array}{l}\text { OTELIN YAPIM } \\
\text { YILI }\end{array}$ & 2010 & 2010 & 2009 \\
\hline ODA SAYISI & $538-540$ & 336 & 231 \\
\hline
\end{tabular}




\begin{tabular}{|l|l|l|l|}
\hline $\begin{array}{l}\text { ENGELLI ODA } \\
\text { SAYISI }\end{array}$ & 6 & 3 & 2 \\
\hline
\end{tabular}

*Oda sayıları 2017'e ait verilerdir.

Yukarıda belirtilen tablodan okunduğu üzere, otellerin bünyesinde barındırdığı engelli odaları, engel gruplarına göre ayrıca sınırlandırımamıştır. Dolayısıyla engelli odalarının her bir engel grubuna hizmet sunması düşünülmüştür.

\subsection{Yöntem}

Çalışma yönteminde; amaç ve kapsamın belirlenerek konu ile ilgili daha önceden yapılmış benzer çalışmalar dair literatürün taranması, tekerlekli sandalye kullanıcıları için düzenlenmiş ulusal ve uluslararası standartların belirlenmesi, alan çalışması için örnek alanlara karar verilmesi, belirlenen örnek alanlara ilişkin ölçümlerin yapılarak ölçüm sonuçlarının tekerlekli sandalye kullanıcılarına yönelik belirlenen standartlara uygunluklarının analiz edilmesi ve tüm bunların doğrultusunda sonuç ve önerilerin geliştirilmesi basamakları belirleyici olmuştur. Çalışmada, İstanbul Pendik İlçesi örneğinde, şehir içi otel odalarının banyo elemanlarının tekerlekli sandalye kullanıcılarının bireylerin kullanılabilirlik bağlamında mevcut standartlara uygunluğu sorgulanmıştır.

Araştırma kapsamında; ulusal çerçevede tekerlekli sandalye kullanıcılarına yönelik hazırlanmış olan standartlar temel alınarak seçilen örnek şehir içi otellerin oda banyolarına ait kapıların özellikleri ve aksamları, lavabo ve çevresi, klozet ve çevresi, yıkanma birimi ve çevresi, zemin döşeme malzemesi olmak üzere donanım/kullanım elemanları incelenmiştir.

Çalışmada; gözlem, yerinde tespit ve fotoğraflama ile verilerin toplanarak analiz edilmesi yöntem olarak seçilmiştir. Seçilen üç otelin girişlerinden iç mekânlarına kullanılabilirlik noktasında elde edilen verilerin analizi; Türk Standardları Enstitüsü tarafından hazırlanan TS 9111 "Özürlüler ve Hareket Kısıtlıığı Bulunan Kişiler İçin Binalarda Ulaşılabilirlik Gerekleri” kılavuzu doğrultusunda belirlenmiş kriterlerle karşılaştırılarak değerlendirilmiştir.

\subsection{Sınırlılıklar}

Çalışmanın gerçekleştirildiği örnek otel alanlarında, verilen izinler ve zaman kısıtı çerçevesinde değerlendirme yapılması sebebiyle araştırmada incelenen kullanılabilirlik parametreleri dışında kalan mekânlar (çalışma alanları, faaliyet alanları, sauna, havuz vb. ortak alanlar) bu araştırma için birer sınırlılık arz etmekte olup, ileride bu konuyla ilgili yapılacak çalışmalara dâhil edilerek literatüre katkı sağlanabilecektir. Ayrıca otellerin isimlerinin çalışmada açıkça belirtilebilmesi için yazılı bir belge edinilemediğinden oteller çalışma içerisinde A Oteli, B Oteli ve C Oteli şeklinde ifade edilmiştir. Bu bakımdan araştırmanın sonuçları bu kapsam ve sınırlııklar doğrultusunda değerlendirilmelidir.

\section{BULGULAR}

Çalışmada, nitel veriler toplanarak yerinde gözlem tekniğiyle Eylül 2017 tarihinde; A Oteli, B Oteli ve C Oteli olmak üzere üç şehir içi oteline gidilmiş ve bu otellerin iç mekânlarının bedensel engelliler açısından kullanılabilirlik kapsamında analizleri yapıımıştır. Çalışmanın birçok teknik veri barındırması sebebiyle bu veriler kategorileştirilerek okunabilirliği açısından tablolaştırımıştır. Çalışmanın temelini 
oluşturan bu üç otelin; kullanılabilirlik kapsamındaki parametreler doğrultusunda çekilen iç mekân fotoğrafları, tavsiye edilen ölçüler, elde edilen bulgular ve yapılması gereken düzenlemelere ait öneriler çalışmada sunulmuştur.

\subsection{Kapıların Özellikleri ve Aksamları}

Örnek seçilen üç otelin oda banyolarının kullanılabilirlik kapsamında "Kapıların Özellikleri ve Aksamları" parametresi doğrultusunda iç mekân fotoğrafları, tavsiye edilen ölçüler ve elde edilen bulguları aşağıdaki gibidir:
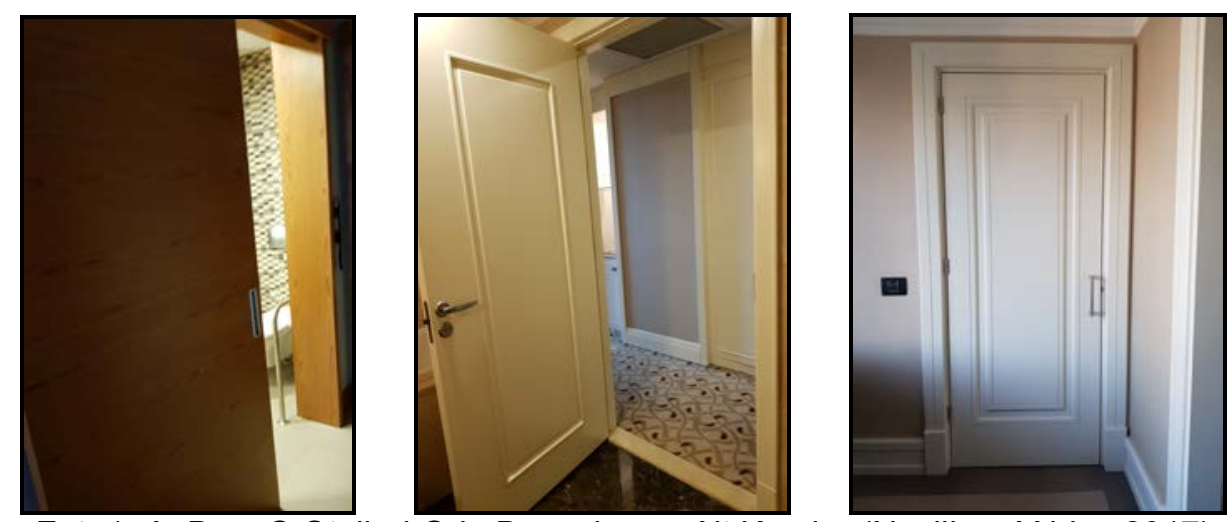

Fot. 1: A, B ve C Otelleri Oda Banyolarına Ait Kapılar (Neslihan Yıldız, 2017)

Çizelge 2: Kullanılabilirlik Kapsamında Kapıların Özellikleri ve Aksamları

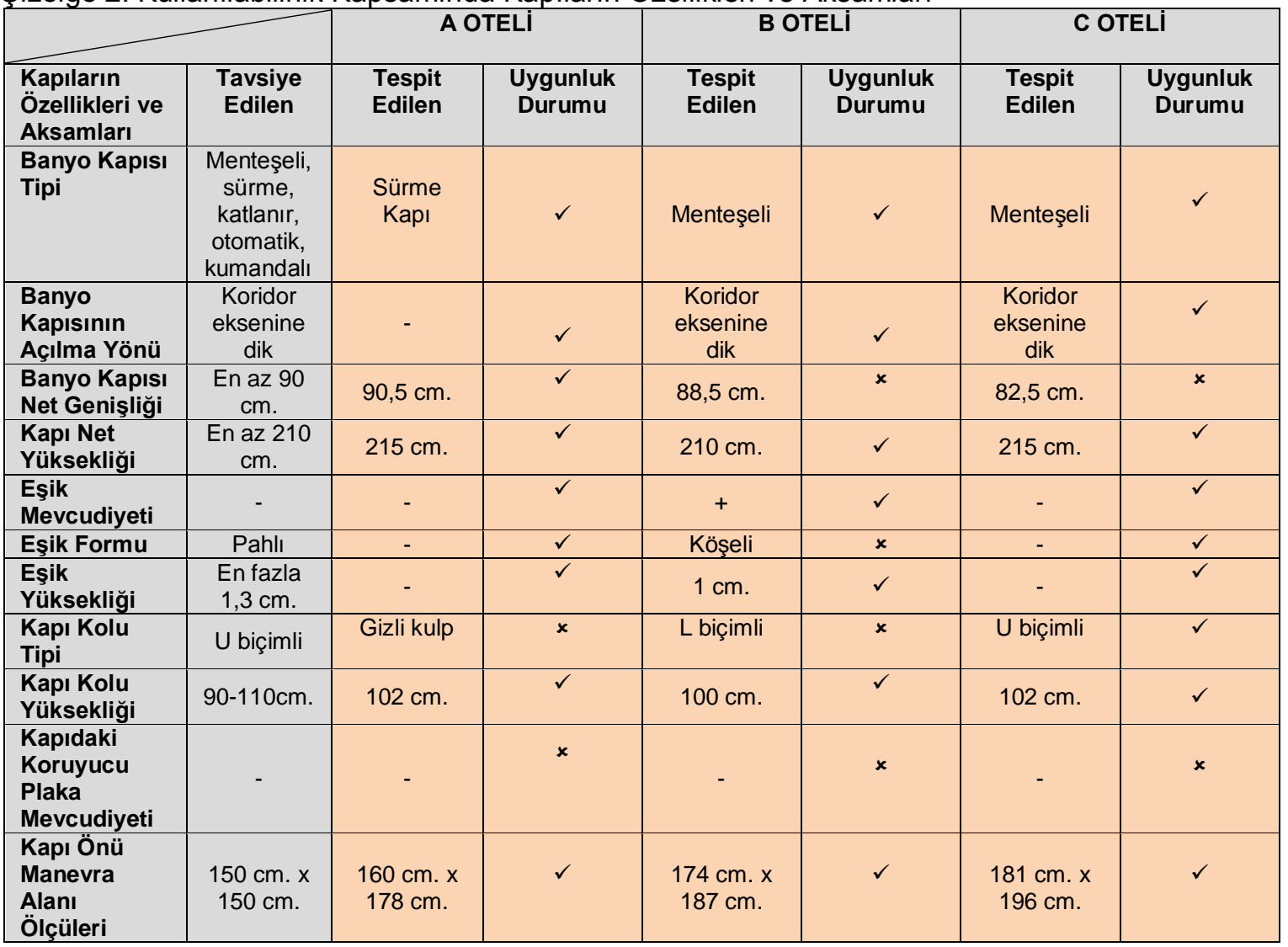




\subsection{Lavabo ve Çevresi}

Örnek seçilen üç otelin oda banyolarının kullanılabilirlik kapsamında "Lavabo ve Çevresi” parametresi doğrultusunda iç mekân fotoğrafları, tavsiye edilen ölçüler ve elde edilen bulguları aşağıdaki gibidir:
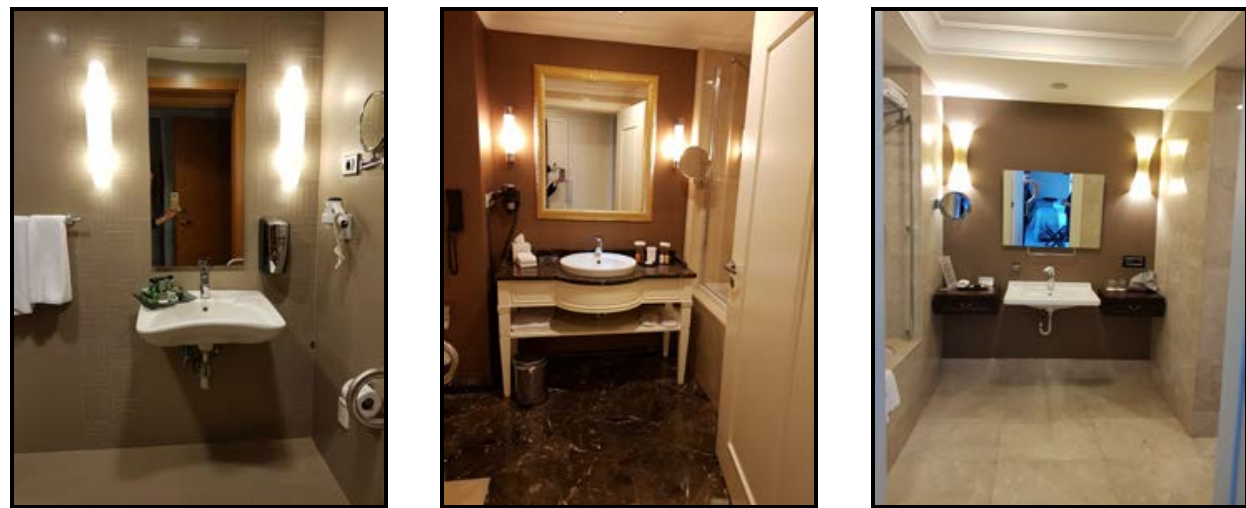

Fot. 2: A, B ve C Otelleri Oda Banyolarına Ait Lavabolar ve Çevresi (Neslihan Yıldız, 2017)
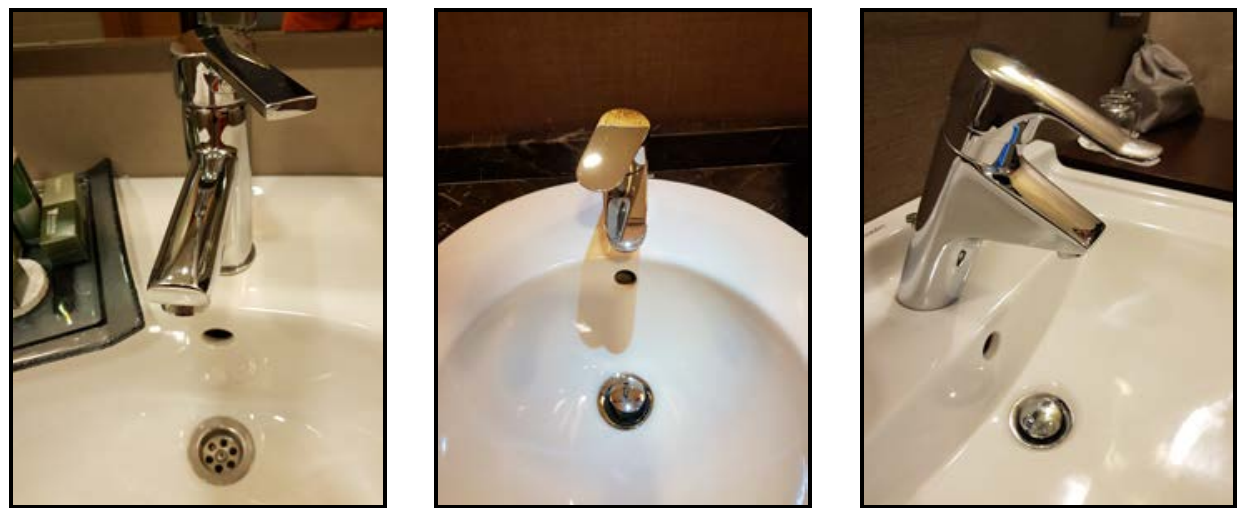

Fot. 3: A, B ve C Otelleri Oda Banyolarına Ait Lavabolar ve Çevreleri (Neslihan Yıldız, 2017)

Çizelge 3: Kullanılabilirlik Kapsamında Lavabo ve Çevresi

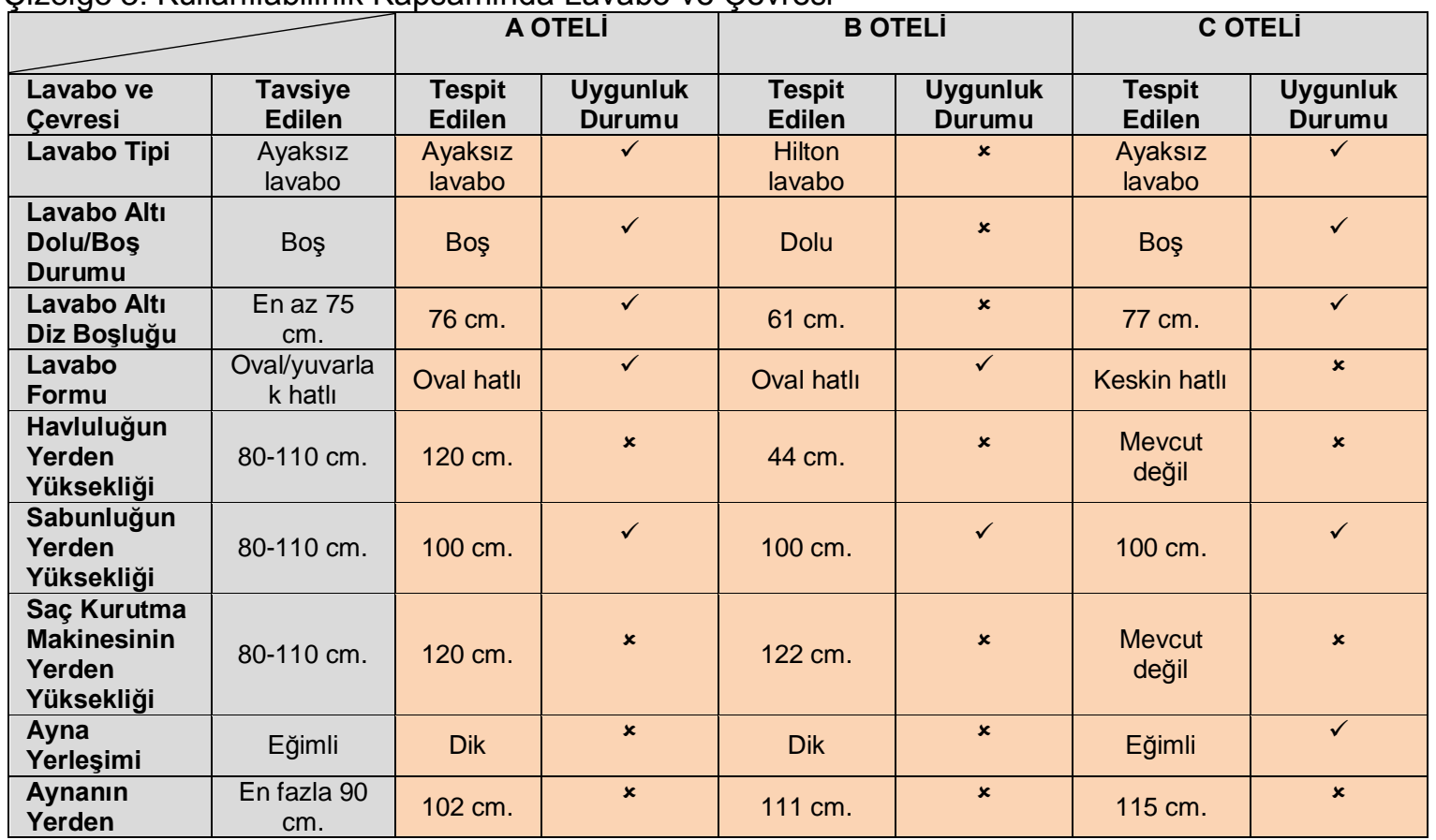




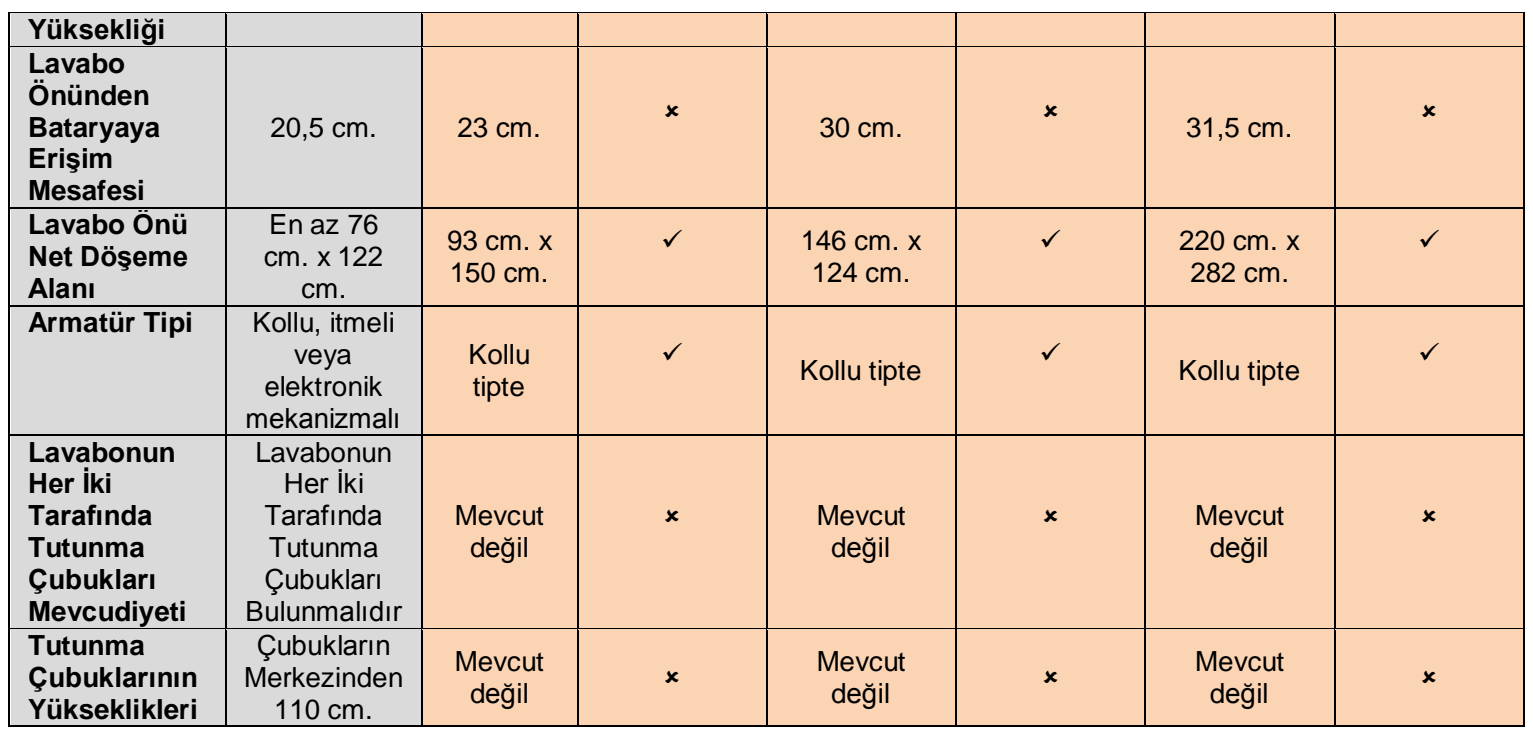

\subsection{Klozet ve Çevresi}

Örnek seçilen üç otelin oda banyolarının kullanılabilirlik kapsamında "Klozet ve Çevresi" parametresi doğrultusunda iç mekân fotoğrafları, tavsiye edilen ölçüler ve elde edilen bulguları aşağıdaki gibidir:
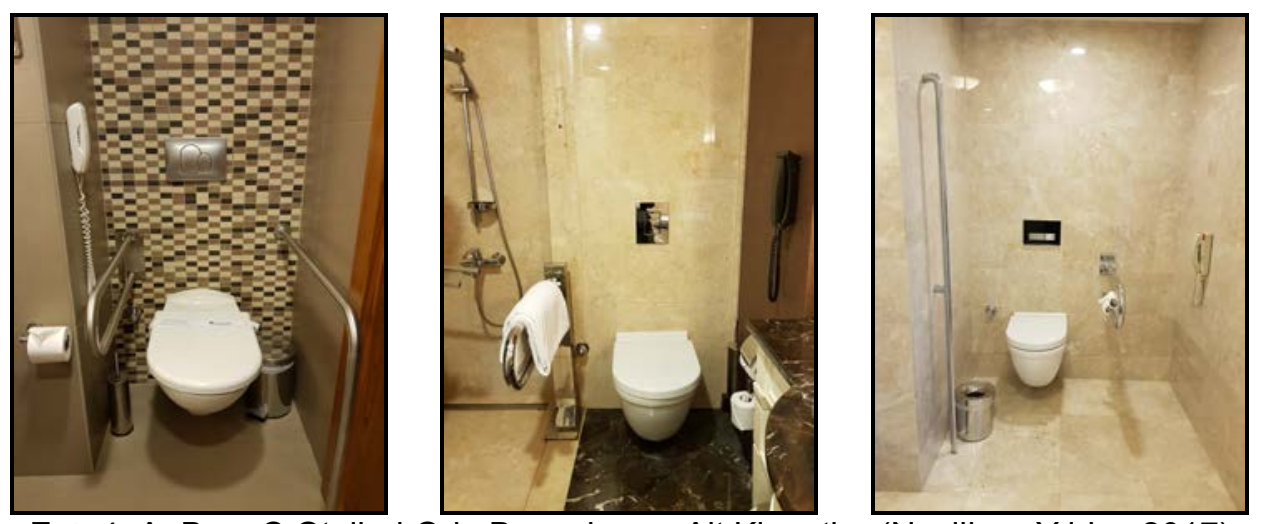

Fot. 4: A, B ve C Otelleri Oda Banyolarına Ait Klozetler (Neslihan Yıldız, 2017)

Çizelge 4: Kullanılabilirlik Kapsamında Klozetler

\begin{tabular}{|c|c|c|c|c|c|c|c|}
\hline \multicolumn{2}{|c|}{ 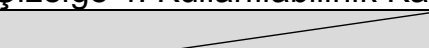 } & \multicolumn{2}{|c|}{ A OTELİ } & \multicolumn{2}{|c|}{ B OTELİ } & \multicolumn{2}{|c|}{ C OTELİ } \\
\hline Klozetler & $\begin{array}{l}\text { Tavsiye } \\
\text { Edilen }\end{array}$ & $\begin{array}{l}\text { Tespit } \\
\text { Edilen }\end{array}$ & $\begin{array}{c}\text { Uygu } \\
\text { nluk } \\
\text { Duru } \\
\text { mu }\end{array}$ & $\begin{array}{l}\text { Tespit } \\
\text { Edilen }\end{array}$ & $\begin{array}{c}\text { Uygunluk } \\
\text { Durumu }\end{array}$ & $\begin{array}{l}\text { Tespit } \\
\text { Edilen }\end{array}$ & $\begin{array}{c}\text { Uygunluk } \\
\text { Durumu }\end{array}$ \\
\hline $\begin{array}{l}\text { Kullanılabilirl } \\
\text { ik Yaklaşım } \\
\text { Tipi }\end{array}$ & $\begin{array}{c}\text { Yandan veya } \\
\text { ortadan } \\
\text { (Mevcut } \\
\text { durum } \\
\text { doğrultusunda } \\
\text { ) }\end{array}$ & $\begin{array}{c}\text { Yandan } \\
\text { yaklaşım }\end{array}$ & $\checkmark$ & $\begin{array}{c}\text { Yandan } \\
\text { yaklaşım }\end{array}$ & $\checkmark$ & $\begin{array}{c}\text { Yandan } \\
\text { yaklaşım }\end{array}$ & $\checkmark$ \\
\hline $\begin{array}{l}\text { Klozet } \\
\text { Yüksekliği }\end{array}$ & $43-48 \mathrm{~cm}$. & $47 \mathrm{~cm}$. & $\checkmark$ & $43 \mathrm{~cm}$ & $\checkmark$ & $50 \mathrm{~cm}$ & $x$ \\
\hline $\begin{array}{l}\text { Adaptör } \\
\text { Takılabilme } \\
\text { Durumu }\end{array}$ & $\begin{array}{c}\text { Adaptör } \\
\text { takılabilen } \\
\text { klozet tercih } \\
\text { edilmeli }\end{array}$ & Mevcut değil & $x$ & $\begin{array}{l}\text { Mevcut } \\
\text { değil }\end{array}$ & $x$ & $\begin{array}{l}\text { Mevcut } \\
\text { değil }\end{array}$ & $x$ \\
\hline $\begin{array}{l}\text { Tekerlekli } \\
\text { Sandalyeden } \\
\text { Transfere }\end{array}$ & $\begin{array}{l}\text { Tekerlekli } \\
\text { sandalyeden } \\
\text { transfere }\end{array}$ & Uygun & $\checkmark$ & Uygun & $\checkmark$ & Uygun & $\checkmark$ \\
\hline
\end{tabular}


Şehir İçi Otel Odalarının Banyolarında Kullanılabilirlik Kavramının Tekerlekli Sandalye Kullanıcıları Açısından Analizi: Pendik'te Üç Otel

\begin{tabular}{|c|c|c|c|c|c|c|c|}
\hline $\begin{array}{l}\text { Uygun Olma } \\
\text { Durumu }\end{array}$ & uygun olmalı & & & & & & \\
\hline $\begin{array}{l}\text { Özel Sifon } \\
\text { Kolu } \\
\text { Kullanımı }\end{array}$ & $\begin{array}{c}\text { Özel sifon kolu } \\
\text { kullanımı } \\
\text { tavsiye edilir } \\
\text { (Fotoselli, el } \\
\text { ile kumandalı } \\
\text { veya otomatik) }\end{array}$ & Mevcut değil & $x$ & $\begin{array}{l}\text { Mevcut } \\
\text { değil }\end{array}$ & $x$ & $\begin{array}{l}\text { Mevcut } \\
\text { değil }\end{array}$ & $x$ \\
\hline $\begin{array}{l}\text { Taharet } \\
\text { Musluğu Tipi }\end{array}$ & $\begin{array}{c}\text { Tek elle kolay } \\
\text { kullanıma } \\
\text { uygun }\end{array}$ & $\begin{array}{c}\text { Tek elle } \\
\text { kolay } \\
\text { kullanıma } \\
\text { uygun }\end{array}$ & $\checkmark$ & $\begin{array}{c}\text { Tek elle } \\
\text { kolay } \\
\text { kullanıma } \\
\text { uygun }\end{array}$ & $\checkmark$ & $\begin{array}{c}\text { Tek elle } \\
\text { kolay } \\
\text { kullanıma } \\
\text { uygun }\end{array}$ & $\checkmark$ \\
\hline $\begin{array}{l}\text { Taharet } \\
\text { Musluğu } \\
\text { Konumu }\end{array}$ & $\begin{array}{c}\text { Kolay } \\
\text { kullanılabilir } \\
\text { konumda }\end{array}$ & $\begin{array}{c}\text { Kolay } \\
\text { kullanılabilir } \\
\text { konumda }\end{array}$ & $\checkmark$ & $\begin{array}{c}\text { Kolay } \\
\text { kullanılabilir } \\
\text { konumda }\end{array}$ & $\checkmark$ & $\begin{array}{c}\text { Kolay } \\
\text { kullanılabilir } \\
\text { konumda }\end{array}$ & $\checkmark$ \\
\hline $\begin{array}{l}\text { Tuvalet } \\
\text { Kâğıtıı̆ının } \\
\text { Konumu } \\
\end{array}$ & $\begin{array}{c}\text { Kolay } \\
\text { kullanılabilir } \\
\text { konumda }\end{array}$ & $\begin{array}{c}\text { Kolay } \\
\text { kullanılabilir } \\
\text { konumda }\end{array}$ & $\checkmark$ & $\begin{array}{c}\text { Kolay } \\
\text { kullanılabilir } \\
\text { konumda }\end{array}$ & $\checkmark$ & $\begin{array}{c}\text { Kolay } \\
\text { kullanılabilir } \\
\text { konumda }\end{array}$ & $\checkmark$ \\
\hline $\begin{array}{l}\text { Tuvalet } \\
\text { Kâğıtlığının } \\
\text { Yerden } \\
\text { Yüksekliği } \\
\end{array}$ & En az $48 \mathrm{~cm}$. & $49 \mathrm{~cm}$. & $\checkmark$ & $55 \mathrm{~cm}$. & $\checkmark$ & $72 \mathrm{~cm}$. & $\checkmark$ \\
\hline $\begin{array}{l}\text { Klozet } \\
\text { Çevresinde } \\
\text { Tutunma } \\
\text { Çubukları } \\
\text { Mevcudiyeti }\end{array}$ & $\begin{array}{c}\text { Klozet } \\
\text { Çevresinde } \\
\text { (Sağ ve sol) } \\
\text { Tutunma } \\
\text { Çubukları } \\
\text { Bulunmalıdır } \\
\end{array}$ & $\begin{array}{l}\text { Mevcut (Sağ } \\
\text { ve sol) }\end{array}$ & $\checkmark$ & $\begin{array}{l}\text { Mevcut } \\
\text { (Sağ) }\end{array}$ & $x$ & $\begin{array}{c}\text { Mevcut } \\
\text { (Sağ ve sol) }\end{array}$ & $\checkmark$ \\
\hline $\begin{array}{l}\text { Tutunma } \\
\text { Çubuklarının } \\
\text { Yükseklikleri }\end{array}$ & $80-95 \mathrm{~cm}$. & $75 \mathrm{~cm}$. & $x$ & $73 \mathrm{~cm}$. & $x$ & $\begin{array}{c}\text { Yatay } 63 \\
\mathrm{~cm} . / \text { Düşey } \\
85 \mathrm{~cm} . \\
\end{array}$ & $\checkmark$ \\
\hline $\begin{array}{l}\text { Tutunma } \\
\text { Çubuklarıyla } \\
\text { Duvar } \\
\text { Arasındaki } \\
\text { Mesafe }\end{array}$ & $4 \mathrm{~cm}$. & $4 \mathrm{~cm}$. & $\checkmark$ & $4 \mathrm{~cm}$ & $\checkmark$ & $4 \mathrm{~cm}$. & $\checkmark$ \\
\hline
\end{tabular}

\subsection{Yıkanma Birimi ve Çevresi}

Örnek seçilen üç otelin oda banyolarının kullanılabilirlik kapsamında "Yıkanma Birimi ve Çevresi” parametresi doğrultusunda iç mekân fotoğrafları, tavsiye edilen ölçüler ve elde edilen bulguları aşağıdaki gibidir:

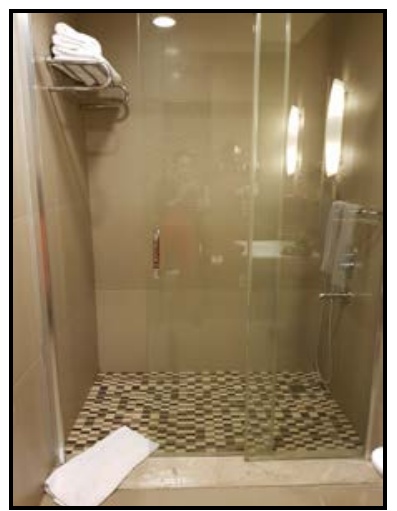

Fot. 5: A Oteli Oda Banyosuna Ait Duş (Neslihan Yıldız, 2017) 


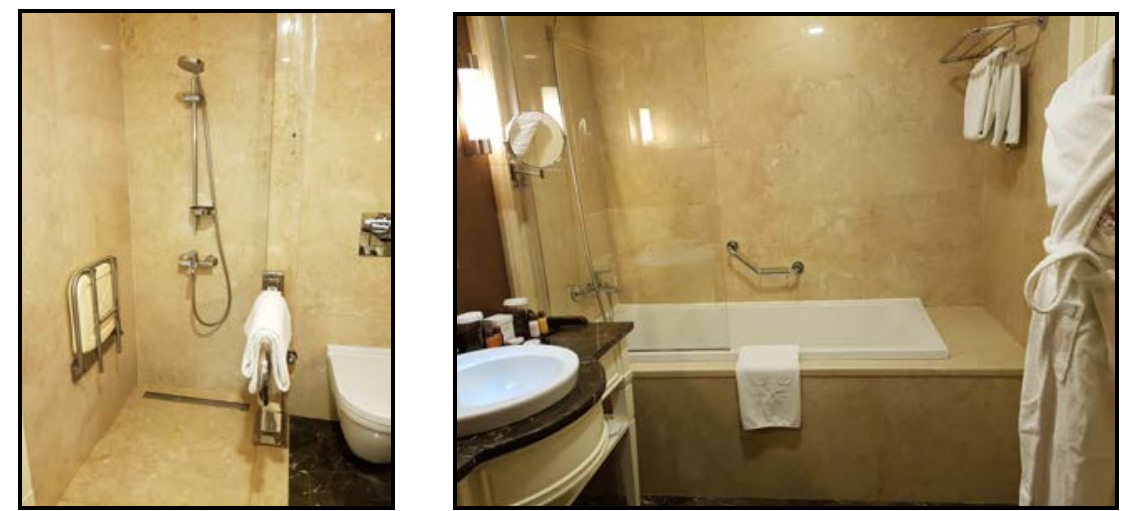

Fot. 6: B Oteli Oda Banyosuna Ait Duş ve Küvet (Neslihan Yıldız, 2017)

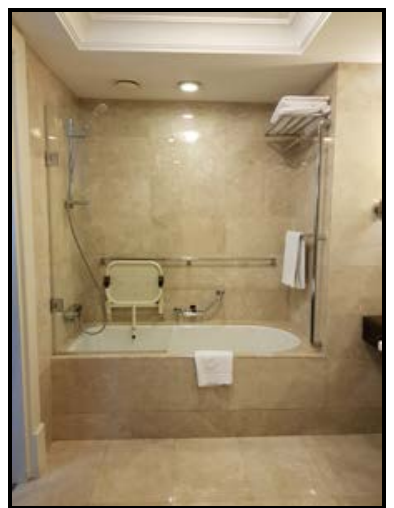

Fot. 7: C Oteli Oda Banyosuna Ait Küvet (Neslihan Yıldız, 2017)

Çizelge 5: Kullanılabilirlik Kapsamında Yıkanma Birimi ve Çevresi
A OTELI

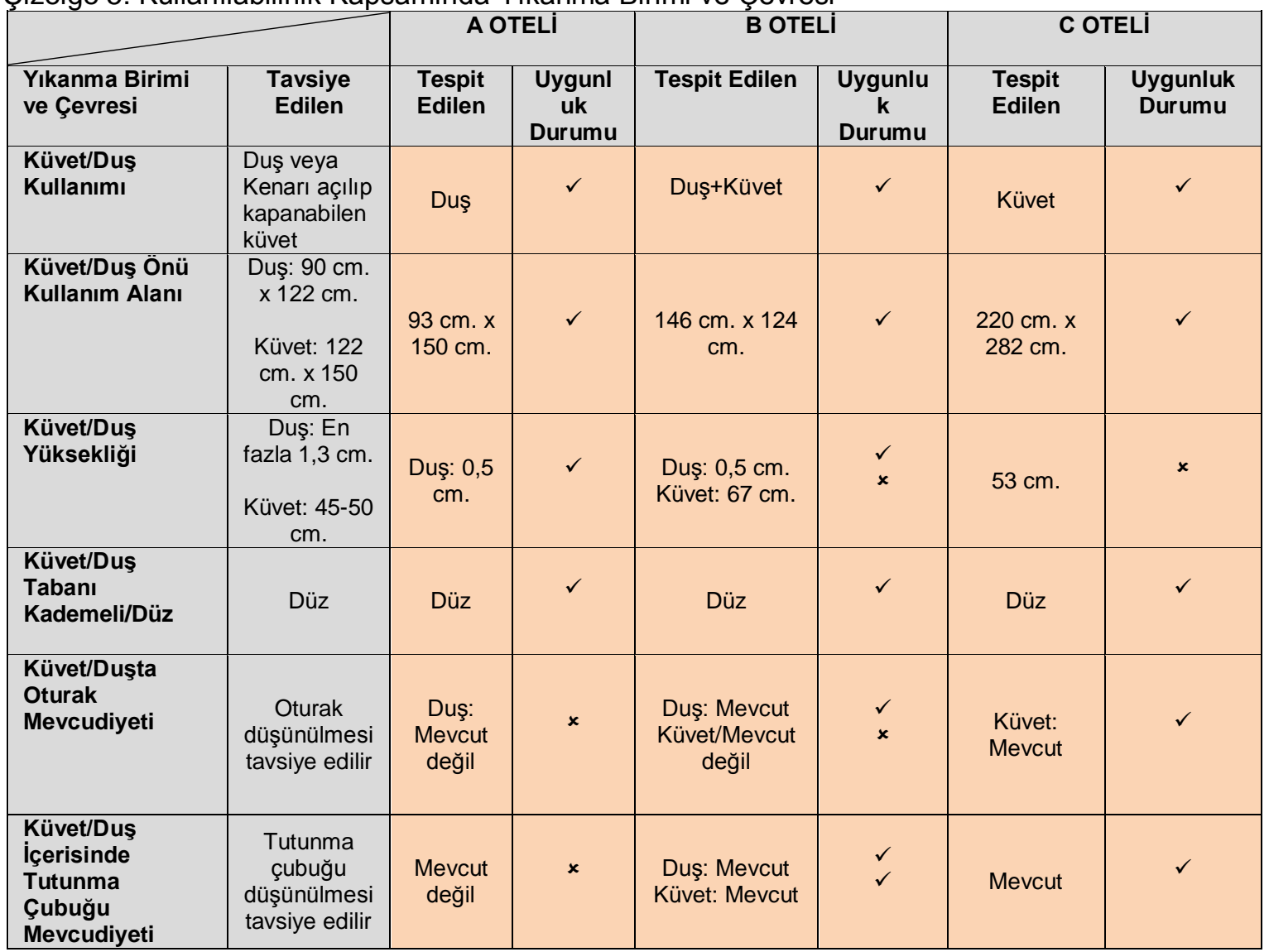


Şehir İçi Otel Odalarının Banyolarında Kullanılabilirlik Kavramının Tekerlekli Sandalye Kullanıcıları Açısından Analizi: Pendik'te Üç Otel

\begin{tabular}{|c|c|c|c|c|c|c|c|}
\hline $\begin{array}{l}\text { Küvet Kenarının } \\
\text { Et Kalınlığı } \\
\text { Ölçüsü }\end{array}$ & $8-12 \mathrm{~cm}$. & - & $\checkmark$ & $11 \mathrm{~cm}$. & $\checkmark$ & $8 \mathrm{~cm}$. & $\checkmark$ \\
\hline $\begin{array}{l}\text { Küvet/Duş } \\
\text { Ebatları }\end{array}$ & $\begin{array}{c}\text { Duş/Küvet: } \\
\text { En az } 95 \\
\mathrm{~cm} . \text { x } 95 \mathrm{~cm} . \\
\text { veya } \\
76 \mathrm{~cm} . \times 150 \\
\mathrm{~cm}\end{array}$ & $\begin{array}{c}\text { Duş:120 } \\
\text { cm. } \\
\text { x150 } \\
\text { cm. }\end{array}$ & $\checkmark$ & $\begin{array}{l}\text { Duş: } 90 \mathrm{~cm} . x \\
130 \mathrm{~cm} . \\
\text { Küvet: } 80 \mathrm{~cm} . \\
\text { x150 cm. }\end{array}$ & $\checkmark$ & $\begin{array}{l}\text { Küvet: } 80 \\
\text { cm. x } 150 \\
\text { cm. }\end{array}$ & $\checkmark$ \\
\hline Duş Başlığı Tipi & $\begin{array}{c}\text { Hem sabit } \\
\text { hem de elle } \\
\text { tutulur } \\
\text { şekilde } \\
\text { kullanmaya } \\
\text { uygun } \\
\text { olmalıdır. }\end{array}$ & $\begin{array}{l}\text { Duş: } \\
\text { Elle } \\
\text { tutulur }\end{array}$ & $x$ & $\begin{array}{l}\text { Duş: Hem } \\
\text { sabit hem de } \\
\text { elle tutulur } \\
\text { Küvet: Hem } \\
\text { sabit hem de } \\
\text { elle tutulur }\end{array}$ & $\checkmark$ & $\begin{array}{l}\text { Küvet: Hem } \\
\text { sabit hem } \\
\text { de elle } \\
\text { tutulur }\end{array}$ & $\checkmark$ \\
\hline $\begin{array}{l}\text { Küvet/Duş } \\
\text { İçerisindeki } \\
\text { Oturağın } \\
\text { Yüksekliği }\end{array}$ & $43-48,5 \mathrm{~cm}$ & - & $x$ & $43 \mathrm{~cm}$. & $\checkmark$ & $58 \mathrm{~cm}$. & $x$ \\
\hline $\begin{array}{l}\text { Küvet/Duş } \\
\text { İçerisindeki } \\
\text { Oturağın Arka } \\
\text { Duvardan } \\
\text { Mesafesi }\end{array}$ & $\begin{array}{c}\text { En fazla } 3,8 \\
\text { cm. }\end{array}$ & - & $x$ & $3,5 \mathrm{~cm}$. & $\checkmark$ & $4 \mathrm{~cm}$. & $x$ \\
\hline $\begin{array}{l}\text { Küvet/Duş } \\
\text { İçerisindeki } \\
\text { Oturağın Yan } \\
\text { Duvardan } \\
\text { Mesafesi }\end{array}$ & $\begin{array}{c}\text { En fazla } 3,8 \\
\text { cm. }\end{array}$ & - & $x$ & $16 \mathrm{~cm}$. & $x$ & $10 \mathrm{~cm}$. & $x$ \\
\hline $\begin{array}{l}\text { Küvet/Duş } \\
\text { İçerisindeki } \\
\text { Oturağın Ebatları } \\
\text { (En x Boy) }\end{array}$ & $\begin{array}{c}\text { En az } 60 \\
\mathrm{~cm} .\end{array}$ & - & $x$ & $\begin{array}{c}60 \mathrm{~cm} . \times 60 \\
\mathrm{~cm} .\end{array}$ & $\checkmark$ & $\begin{array}{c}60 \mathrm{~cm} . \times 80 \\
\mathrm{~cm} .\end{array}$ & $\checkmark$ \\
\hline $\begin{array}{l}\text { Duş Biriminde } \\
\text { Koruma Bordürü } \\
\text { Mevcudiyeti }\end{array}$ & $\begin{array}{c}\text { Küvet } \\
\text { tercihinde } \\
\text { yapılmasına } \\
\text { gerek } \\
\text { yoktur. Duş } \\
\text { tercihinde } \\
\text { ise en fazl } \\
1,3 \mathrm{~cm} . \\
\end{array}$ & Mevcut & $\checkmark$ & $\begin{array}{l}\text { Duş: Mevcut } \\
\text { Küvet: Mevcut } \\
\text { değil }\end{array}$ & $\checkmark$ & $\begin{array}{l}\text { Küvet: } \\
\text { Mevcut } \\
\text { değil }\end{array}$ & $\checkmark$ \\
\hline $\begin{array}{l}\text { Duş Biriminde } \\
\text { Koruma Bordürü } \\
\text { Yüksekliği }\end{array}$ & $\begin{array}{c}\text { En fazla } 1,3 \\
\mathrm{~cm} .\end{array}$ & $1 \mathrm{~cm}$. & $\checkmark$ & $1 \mathrm{~cm}$. & $\checkmark$ & - & - \\
\hline
\end{tabular}

\subsection{Zemin Döşeme Malzemesi}

Örnek seçilen üç otelin oda banyolarının kullanılabilirlik kapsamında "Zemin Döşeme Malzemesi” parametresi doğrultusunda iç mekân fotoğrafları, tavsiye edilen ölçüler ve elde edilen bulguları aşağıdaki gibidir: 

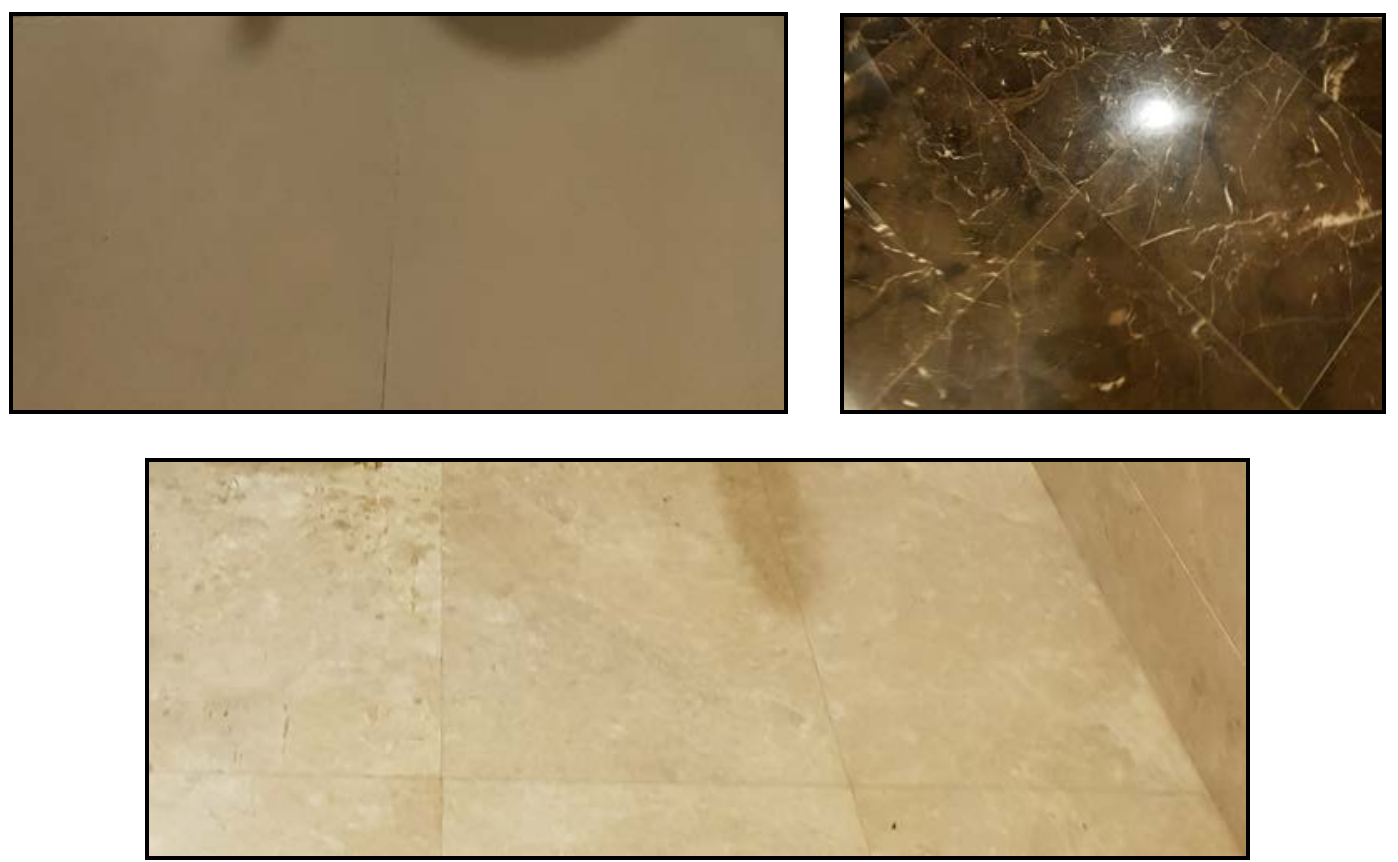

Fot. 8: A,B ve C Otelleri Oda Banyosuna Ait Zemin Döşemeleri (Neslihan Yıldız, 2017)

\begin{tabular}{|c|c|c|c|c|c|c|c|}
\hline & \multicolumn{2}{|c|}{ A OTELI } & \multicolumn{2}{|c|}{ B OTELI } & \multicolumn{2}{|c|}{ C OTELI } \\
\hline $\begin{array}{l}\text { Zemin } \\
\text { Dösseme } \\
\text { Malzemesi }\end{array}$ & $\begin{array}{l}\text { Tavsiye } \\
\text { Edilen }\end{array}$ & $\begin{array}{l}\text { Tespit } \\
\text { Edilen }\end{array}$ & $\begin{array}{l}\text { Uygunluk } \\
\text { Durumu }\end{array}$ & $\begin{array}{l}\text { Tespit } \\
\text { Edilen }\end{array}$ & $\begin{array}{l}\text { Uygunluk } \\
\text { Durumu }\end{array}$ & $\begin{array}{l}\text { Tespit } \\
\text { Edilen }\end{array}$ & $\begin{array}{c}\text { Uygunluk } \\
\text { Durumu }\end{array}$ \\
\hline $\begin{array}{l}\text { Döşemede } \\
\text { Seviye Farkı } \\
\text { Mevcudiyeti }\end{array}$ & $\begin{array}{c}\text { Seviye farkı } \\
\text { önerilmemek } \\
\text { tedir. } \\
\text { Yapılması } \\
\text { gerektiği } \\
\text { durumlarda } \\
\text { en fazla } 0,6 \\
\mathrm{~cm} .\end{array}$ & Mevcut & $\checkmark$ & Mevcut & $\checkmark$ & $\begin{array}{l}\text { Mevcut } \\
\text { değil }\end{array}$ & $\checkmark$ \\
\hline $\begin{array}{l}\text { Seviye Farkı } \\
\text { Yüksekliği }\end{array}$ & $\begin{array}{c}\text { En fazla } 0,6 \\
\mathrm{~cm} .\end{array}$ & $0,5 \mathrm{~cm}$. & $\checkmark$ & $0,5 \mathrm{~cm}$. & $\checkmark$ & $\begin{array}{c}\text { Mevcut } \\
\text { değil }\end{array}$ & $\checkmark$ \\
\hline $\begin{array}{l}\text { Banyo Gideri } \\
\text { Tasarımı }\end{array}$ & $\begin{array}{c}\text { Kapı önünde } \\
\text { su } \\
\text { birikmesini } \\
\text { önleyecek } \\
\text { şekilde }\end{array}$ & $\begin{array}{c}\text { Kapı } \\
\text { önünde su } \\
\text { birikmesini } \\
\text { önleyecek } \\
\text { şekilde }\end{array}$ & $\checkmark$ & $\begin{array}{c}\text { Kapı } \\
\text { önünde su } \\
\text { birikmesini } \\
\text { önleyecek } \\
\text { şekilde }\end{array}$ & $\checkmark$ & $\begin{array}{c}\text { Kapı } \\
\text { önünde su } \\
\text { birikmesini } \\
\text { önleyecek } \\
\text { şekilde }\end{array}$ & $\checkmark$ \\
\hline $\begin{array}{l}\text { Zemin } \\
\text { Döşeme } \\
\text { Yüzey } \\
\text { Özelliği }\end{array}$ & $\begin{array}{l}\text { Kaymayan } \\
\text { (Islak/Kuru) } \\
\text { özellikte }\end{array}$ & $\begin{array}{l}\text { Kaymayan } \\
\text { (Islak/Kuru } \\
\text { ) özellikte }\end{array}$ & $\checkmark$ & $\begin{array}{c}\text { Kaymayan } \\
\text { (Islak/Kuru) } \\
\text { özelliğe } \\
\text { sahip değil }\end{array}$ & $x$ & $\begin{array}{c}\text { Kaymayan } \\
\text { (Islak/Kuru) } \\
\text { özellikte }\end{array}$ & $\checkmark$ \\
\hline
\end{tabular}

\section{SONUÇ VE ÖNERILER}

Alan çalışması kapsamında tekerlekli sandalye kullanıcıları için ulusal standartlar ve ölçüler göz önünde bulundurularak bir çalışma yapılmıştır. Bu çalışmada, şehir içi otel iç mekânlarının tekerlekli sandalye kullanıcıları açısından kullanılabilirlik kapsamında incelenmesi ve herkes için olduğu gibi tekerlekli sandalye kullanıcıları için de konaklanabilir otellerin tasarlanması veya yapılacak düzenlemelerle konaklanabilir otellere dönüştürülmesi amaçlanmıştır. Bu çalışmada bir diğer amaç, kullanılabilirlik kapsamında tekerlekli sandalye kullanıcılarının hiç kimsenin yardımına intiyaç duymadan ve hareket kısıtlılı̆ı yaşamadan şehir içi otellerin tüm hizmetlerinden faydalanabilmelerinin sağlanmasıdır. 
İncelenen şehir içi otel binalarında; kapıların özellikleri ve aksamları, lavabo ve çevresi, klozet ve çevresi, yıkanma birimi ve çevresi, zemin döşeme malzemesi olmak üzere tekerlekli sandalye kullanıcılarının bu birimleri kullanılabilirlikleri, uygulanması gereken düzenlemeler tablosundan okunabileceği üzere kolay bir şekilde sağlanamamaktadır.

Alan çalışmasında kullanılabilirlik kapsamında elde edilen verilere göre geliştirilen öneriler aşağıdaki şekildedir:

\section{Kapıların özellikleri ve aksamları;}

- $\quad B$ ve $C$ otellerinin banyo kapılarında net genişliğin sağlanamadığı görülmektedir. $\mathrm{Bu}$ durum tekerlekli sandalye kullanıcılarının geçişine etki edeceğinden kapıların net genişliği tavsiye edilen genişliğe getirilmelidir.

- B otelinin banyo kapısında bulunan eşik köşeli forma sahip olduğu tespit edilmiştir. Tekerlekli sandalyenin rahat geçişi için pahlı olacak şekilde tekrar düzenlenmelidir.

- A ve $B$ otellerinin banyo kapı kollarının "L" biçiminde olduğu görülmektedir. Kullanılabilirlik açısından tavsiye edilen şekilde ( $U$ biçimli) kapı kolları monte edilmelidir.

- Her üç otelin banyo kapısında koruyucu plaka düşünülmemiştir. Tekerlekli sandalye ile kapıya önden yaklaşımda kapıya zarar verilmemesi adına banyo kapılarına koruyu plaka monte edilmelidir.

\section{Lavabo ve çevresi;}

- B otelinde lavabo tipi olarak hilton lavabo kullanıldığı ve lavabo altının dolu kurgulandığı görülmektedir. Tekerlekli sandalye için sağlanması gereken diz boşluğu mesafesinin bırakılmadığı görülmektedir. Lavabonun kullanılabilir olması açısından gerekli diz boşluğu mesafesinin düzenlenmesi gerekirse lavabo tipinin değiştirilmesi gerekmektedir.

- A ve B otellerinin lavabo çevresinde mevcut olan havlulukların, kullanılabilirlik çerçevesinde yüksekliklerinin uygun olmadığı tespit edilmiş, $C$ otelinde ise mevcutta bir havluluğa rastlanmamıştır. A ve B otellerinde; tekerlekli sandalye kullanıcısının rahat erişimi ve kullanımı açısından havluluklar tavsiye edilen yüksekliğe taşınmalı, C otelinde ise; lavabo çevresinde uygun konuma ve yüksekliğe bir havluluk monte edilmelidir.

- A ve B otellerinin lavabo çevresinde mevcut olan saç kurutma makinelerinin, kullanılabilirlik çerçevesinde yüksekliklerinin uygun olmadığı tespit edilmiş, C otelinde ise mevcutta bir saç kurutma makinesine rastlanmamıştır. A ve $B$ otellerinde; tekerlekli sandalye kullanıcısının rahat erişimi ve kullanımı açısından saç kurutma makineleri tavsiye edilen yüksekliğe taşınmalı, C otelinde ise; lavabo çevresinde uygun konuma ve yüksekliğe bir saç kurutma makinesi monte edilmelidir.

- A ve B otellerinde lavabo çevresindeki aynaların yerleşimi dik şekilde yapılmıştır. Tekerlekli sandalye kullanıcısının oturur vaziyetteyken aynayı rahat kullanabilmesi açısından aynaların eğimli duruma getirilmesi gerekmektedir.

- Her üç otelde aynaların döşeme üzerinden olan yüksekliklerinin tavsiye edilen ölçüye uygun olmadığı tespit edilmiştir. Tekerlekli sandalye kullanıcısının kullanılabilirliğinin sağlanması açısından ayna yüksekliklerinin gereken ölçüde monte edilmesi gerekmektedir.

- Her üç otelde lavabo önünden bataryaya erişim mesafelerinin fazla tutulduğu görülmektedir. Tekerlekli sandalye kullanıcısının lavaboya rahat erişimi ve 
lavaboyu rahat kullanabilmesi açısından bu erişim mesafelerinin tavsiye edilen ölçüde düzenlenmesi gerekmektedir. Bu noktada lavabo ve batarya tipi, tezgâh kurgusu yeniden düşünülmelidir.

- Yine her üç otelde lavabonun her iki tarafında tutunma çubukları düşünülmediği görülmektedir. Ayakta durmakta zorlanan bireyler de düşünülerek bu üç otelin lavabolarına, her iki tarafında olacak şekilde tavsiye edilen ölçü ve yükseklikte tutunma çubukları yerleştirilmelidir.

Klozet ve çevresi;

- C otelinde klozet yüksekliğinin fazla olduğu tespit edilmiştir. Rahat kullanım açısından bu ölçü tavsiye edilen şekilde düzenlenmelidir. Ayrıca kullanıcının ergonomik ölçülerine cevap verebilmesi adına her üç otel için adaptör takılabilen klozetler tercih edilmelidir.

- Her üç otelde özel sifon kolu tercih edilmemiştir. Tekerlekli sandalye kullanıcısı manuel sifon kolunu kullanmakta zorlanacağından tavsiye edilen alternatiflerde (Fotoselli, el ile kumandalı veya otomatik) sifon kolu kullanılmalıdır.

- B otelinde klozetin tek bir kenarına tutunma çubuğu yerleştirildiği gözlenmiştir. Tekerlekli sandalye kullanıcısının klozete transferi esnasında iki taraflı destek alabileceği tutunma çubuklarının mevcudiyeti bu noktada önem arz etmektedir. Dolayısıyla bu otel klozeti için iki taraflı tutunma çubuğu düzenlenmelidir.

- A ve B otellerinde klozet çevresindeki mevcut tutunma çubuklarının yükseklikleri tavsiye edilen ölçüde bulunmamaktadır. $\mathrm{Bu}$ durum tekerlekli sandalye kullanıcısını zorlayacağından bu iki otelin klozet çevresi için tutunma çubukları belirtilen yükseklikte düzenlenmelidir.

Yıkanma birimi ve cevresi;

- A otelinde duş birimi içerisinde oturak düşünülmediği tespit edilmiştir. Tekerlekli sandalye kullanıcısının duş kullanımını sağlamak adına muhakkak duş birimi içerisine bir oturak yerleştirilmelidir.

- A otelinde duş birimi içerisinde tutunma çubuğu yerleştirilmediği görülmektedir. Tekerlekli sandalye kullanıcısının destek alabilmesi açısından duş birimi içerisine tavsiye edilen ölçü ve yükseklikte tutunma çubukları yerleştirilmelidir.

- Yine A otelinde duş başlığı tipinin yalnızca elle tutulur özellikte olduğu görülmektedir. Fakat duş başlığının kullanılabilir olması açısından hem sabit hem elle tutulur özellikte olması tavsiye edilmektedir. Dolayısıyla A otelinin duş biriminde duş başlığı tavsiye edilen şekilde değiştirilmelidir.

- C otelinde küvet içerisinde oturak düşülmesine karşın bu oturağın yüksekliği tavsiye edilen ölçülere uygunluk göstermemektedir. Kullanılabilirliğin sağlanması açısından bu oturağın uygun yüksekliğe yerleştirilmesi gerekmektedir.

- A ve C otellerinde duş/küvet içerisindeki oturakların arka duvardan mesafeleri, her üç otelde ise duş/küvet içerisindeki oturakların yan duvardan mesafeleri tavsiye edilen ölçünün dışındadır. Bu mesafeler, kullanıcı oturur, arka duvara yaslanır veya yan duvara yaslanır vaziyetteyken tehlike yaratabilir. Dolayısıyla oturakların arka ve yan duvardan olan mesafeleri önerilen ölçüler doğrultusunda düzenlenerek, tekrardan monte edilmesi gerekmektedir.

- Bunlara ilaveten küvet düşünülen otellerde küvet içerisinde tekerlekli sandalye kullanıcısı açısından bir takım tavsiye edilen ölçüler tutarlılık gösteriyor olsa bile küvetlerin kenarı açılıp kapanabilen özel küvetler olarak kurgulanmaları gerekmektedir. Mevcut halde tekerlekli sandalye kullanıcısının kullanımına uygun değildir. 


\section{Zemin döșeme malzemesi;}

- B otelinde zemin döşeme yüzey özelliğinin, kaymayan (ıslak/kuru) özellikte olmadığı görülmektedir. Bu durum ıslak hacim kurgusunda kullanıcı açısından tehlikelere yol açabilmektedir. Dolayısıyla B otelinde banyo zemin döşemesi değiştirilerek kaymayan (ıslak/kuru) özellikte bir zemin döşemesi uygulanmalıdır.

Şehir içi otelleri tasarlanmadan önce farklı kullanıcı grupları ile ilgili istatistiksel veriler toplanır ve konuyla ilgili araştırma yapılırsa, engelli kullanıcılar dahil tüm kullanıcı grupları otelde konakladıkları süre boyunca günlük yaşantılarındaki tüm fonksiyonları yerine getirebileceklerdir. Ayrıca genel olarak tekerlekli sandalye kullanıcılarının ölçülerinin verilmesi yerine farklı yapı grupları (eğitim yapıları, kamu yapıları, otel yapıları vs.) ve kapsadığı mekânlar için yalnızca tekerlekli sandalye kullanıcıları adına oluşturulmuş bir el kitabı hazırlanmalıdır. İnşa edilmiş şehir içi otellerinin incelenmesiyle ilçedeki engelli konaklama ölçütlerinin uygunluğu tespit edilmiş, elde edilen bulguların bundan sonra inşa edilecek veya düzenlemeye gidilecek şehir içi otellerin tasarımında bu açıdan belirleyici olabileceği ve çalışmanın gelecekte yapılacak benzer çalışmalara ışık tutabileceği düşünülmüştür. 


\section{KAYNAKÇA}

Akçakaya, E. (2014). Kent Otellerinin Güncel Tasarım Kriterleri (Yüksek Lisans Tezi, İstanbul Teknik Üniversitesi, İstanbul). Erişim adresi: https://polen.itu.edu.tr/bitstream/11527/8566/1/14346.pdf

Burak, Y. (2018). Konaklama Tesislerinin Engelli Bireylere Uygunluk Açısından Değerlendirilmesi: Sivil Toplum Kuruluşlarındaki Engelli Üyelerin Bakış Açısı (Yüksek Lisans Tezi, Selçuk Üniversitesi, Konya). Erişim adresi: http://acikerisimarsiv.selcuk.edu.tr:8080/xmlui/bitstream/handle/123456789/142 93/504180. pdf?sequence=1\&isAllowed=y

Demirkan, H. (2015). Mekanlarda Erişilebilirlik, Kullanılabilirlik ve Yaşanabilirlik. Tmmob Mimarlar Odası Ankara Şubesi Dergisi, 36, 1-4. Erişim adresi: http://www.mimarlarodasiankara.org/dosya/dosya36.pdf

ISO 9241, (1998). Ergonomic requirements for office work with visual display terminals (VDTs), Part 12: Presentation of information. International Organization for Standardization.

Karahasanoğlu, E. B. (2004). Beş Yıldızı Şehir Otellerinin İşletme Modelleri ve Mimari Tasarım Kimliği Etkileşimi (Yüksek Lisans Tezi, İstanbul Teknik Üniversitesi, İstanbul). Erişim adresi: https://polen.itu.edu.tr/bitstream/11527/9520/1/2265.pdf

MEB, (2008). Özel Öğretim Kurumları Genel Müdürlüğü, Özel Eğitim ve Rehabilitasyon Merkezi Bedensel Engelli Bireyler Destek Eğitim Programı, 2008.

Muğan, G. (2015). Alışveriş Merkezi (Avm) Tasarımlarında Erişilebilir, Kullanılabilir ve Yaşanabilir Tasarım Yaklaşımları. Tmmob Mimarlar Odası Ankara Şubesi Dergisi, 36, 43-53. Erişim adresi: http://www.mimarlarodasiankara.org/dosya/dosya36.pdf

TS 9111, (1991). Özürlü İnsanların İkamet Edeceği Binala-rın Düzenlenmesi Kuralları.Türk Standardları Enstitüsü.

Yılmaz, B. (2005). Bedensel Engelli Çocukların Temel Eğitim Okullarında Eğitim Alabilmesi İçin Gereken Mimari Düzenlemeler. Selçuk Üniversitesi Mühendislik Mimarlık Fakültesi Dergisi, 20/3, 73-84. Erişim adresi: https://dergipark.org.tr/tr/download/article-file/216010 